\title{
Photogenerated Reactive Oxygen Species and Hyperthermia by Cu3SnS4 Nanoflakes for Advanced Photocatalytic and Photothermal Antibacterial Therapy
}

\section{Yangzi Yang}

Shanghai 9th Peoples Hospital Affiliated to Shanghai Jiaotong University School of Medicine Chengwei Wang

Shanghai 9th Peoples Hospital Affiliated to Shanghai Jiaotong University School of Medicine Ning Wang

Shanghai 9th Peoples Hospital Affiliated to Shanghai Jiaotong University School of Medicine Jiaxin Li

Shanghai 9th Peoples Hospital Affiliated to Shanghai Jiaotong University School of Medicine Yingchun Zhu

Chinese Academy of Sciences

Jiantao Zai

Shanghai Jiao Tong University

Jingke Fu

Shanghai 9th Peoples Hospital Affiliated to Shanghai Jiaotong University School of Medicine

Yongqiang Hao ( $\nabla$ hyq_9hospital@hotmail.com )

Shanghai 9th Peoples Hospital Affiliated to Shanghai Jiaotong University School of Medicine https://orcid.org/0000-0003-4454-4221

\section{Research Article}

Keywords: reactive oxygen species, Cu3SnS4, photocatalytic, photothermal, antibacterial therapy.

Posted Date: January 31st, 2022

DOI: https://doi.org/10.21203/rs.3.rs-1291866/v1

License: (9) (1) This work is licensed under a Creative Commons Attribution 4.0 International License. Read Full License 
Version of Record: A version of this preprint was published at Journal of Nanobiotechnology on April 20th, 2022. See the published version at https://doi.org/10.1186/s12951-022-01403-y. 


\section{Abstract}

\section{Background}

The rapid spread of infectious bacteria has brought great challenges to public health. It is imperative to explore effective and environment-friendly antibacterial modality to defeat antibiotic-resistant bacteria with high biosafety and broad-spectrum antibacterial property. Results

Herein, biocompatible $\mathrm{Cu}_{3} \mathrm{SnS}_{4}$ nanoflakes (NFs) were prepared by a facile and low-cost fabrication procedure. These $\mathrm{Cu}_{3} \mathrm{SnS}_{4} \mathrm{NFs}$ could be activated by visible light, leading to visible light-mediated photocatalytic generation of a myriad of reactive oxygen species (ROS). Besides, the plasmonic $\mathrm{Cu}_{3} \mathrm{SnS}_{4}$ NFs exhibit strong near infrared (NIR) absorption and a high photothermal conversion efficiency of $55.7 \%$. The ROS mediated cellular oxidative damage and the NIR mediated photothermal disruption of bacterial membranes collaboratively contributed to the advanced antibacterial therapy, which has been validated by the efficient eradication of both Gram-negative Escherichia coli and Gram-positive methicillin-resistant Staphylococcus aureus strains in vitro and in vivo. Meanwhile, the exogenous copper ions metabolism from the $\mathrm{Cu}_{3} \mathrm{SnS}_{4} \mathrm{NFs}$ facilitated the endothelial cell angiogenesis and collagen deposition, thus expediting the wound healing. Importantly, the inherent localized surface plasmon resonance effect of $\mathrm{Cu}_{3} \mathrm{SnS}_{4} \mathrm{NFs}$ empowered them as an active substrate for surface-enhanced Raman scattering (SERS) imaging and SERS-labeled bacteria detection.

\section{Conclusions}

The low cost and biocompatibility together with the solar-driven broad-spectrum photocatalytic/photothermal antibacterial property of $\mathrm{Cu}_{3} \mathrm{SnS}_{4} \mathrm{NFs}$ make them a candidate for sensitive bacteria detection and effective antibacterial treatment.

\section{Background}

The continuous and rapid spread of infectious bacteria has brought great challenges to public health. This challenge has been further exacerbated by the excessive use of antibiotics, which cultivates multidrug-resistant "super-bacteria" that may go out of the control of traditional antibiotics treatment ${ }^{[1]}$. During the past few years, a series of antibacterial materials, such as peptides, polymers, quaternary ammonium salts, metal oxides, and inorganic nanoparticles ${ }^{[2-6]}$, have proven as bactericidal or bacteriostatic agents due to their unique antibacterial mechanisms. Although the great potential of the abovementioned antibacterial materials as alternative antibiotics, further clinical applications are limited by their potential biotoxicity and low antibacterial efficiency. It is imperative to explore more effective and environment-friendly antibacterial modality to defeat antibiotic-resistant bacteria with high biosafety and broad-spectrum antibacterial property. 
Recently, photocatalytic technology has emerged as a promising option for administrating antibioticresistant bacteria in water disinfection ${ }^{[7,8]}$. Photocatalysis involves the use of solar light for activating photocatalysts to split water, followed by the generation of a myriad of reactive oxygen species (ROS) such as hydrogen peroxide $\left(\mathrm{H}_{2} \mathrm{O}_{2}\right)$, hydroxyl radicals $(\cdot \mathrm{OH})$, superoxide radicals $\left(\mathrm{O}_{2}{ }^{-{ }^{-}}\right)$and singlet oxygen $\left({ }^{1} \mathrm{O}_{2}\right)^{[9-11]}$. These ROS could react with proteins, lipids, polysaccharides as well as other constituents of bacteria, leading to oxidative damage of bacterial membrane and ultimate cell death ${ }^{[11-14]}$. It is noteworthy that ROS-based photocatalysis has been revealed to play a vital role in preventing bacterial biofilms formation, showing great potential for even antibiotic-resistant bacteria ${ }^{[15]}$. The ideal properties for photocatalysts in antibacterial therapy are i) facile and low-cost fabrication procedure for future mass application; ii) environment-friendly and high biosafety to normal tissues; iii) efficient photocatalytic reactivity with extended absorption region to achieve full spectrum solar-driven photocatalysis; iv) broadspectrum antibacterial property for even multidrug-resistant bacteria. Ternary $\mathrm{Cu}_{3} \mathrm{SnS}_{4}$ is a p-type semiconductor with a high absorption coefficient $\left(\sim 10^{5} \mathrm{~cm}^{-1}\right)$ and a tunable optical band gap (0.8-1.7 $\mathrm{eV})^{[16]}$. The narrow band gap of $\mathrm{Cu}_{3} \mathrm{SnS}_{4}$ enables it an extended absorption in visible and near infrared (NIR) regions. Since semiconductor photocatalysts such as $\mathrm{ZnO}, \mathrm{TiO}_{2}$ and $\mathrm{Ag}-\mathrm{C}_{3} \mathrm{~N}_{4}$ composite ${ }^{[17]}$ commonly are only active in the ultraviolet (UV) light spectrum, which occupies only $4 \%$ of the solar spectrum ${ }^{[7]}$. The higher and extended optional absorption of $\mathrm{Cu}_{3} \mathrm{SnS}_{4}$ in the visible region (occupies $44 \%$ of the solar spectrum) thus makes it a desired photocatalyst for visible (Vis) light activatable antibacterial applications. More importantly, the plasmonic $\mathrm{Cu}_{3} \mathrm{SnS}_{4}$ exhibits strong NIR absorption and high quantum efficiency, which could be converted to thermal energy and induce NIR based photothermal sterilization ${ }^{[18-20]}$. Notably, unlike the narrow bandgap metal sulfides such as $\mathrm{CdS}, \mathrm{PbS}, \mathrm{ZnInS}_{4}, \mathrm{AgGaS}_{2}$ and $\mathrm{ZnCdS}$, which suffer from drawbacks of elemental toxicity ( $\mathrm{Cd}$ and $\mathrm{Pb}$ ) and higher costs (In and $\mathrm{Ga}$ ). The $\mathrm{Cu}_{3} \mathrm{SnS}_{4}$ is consisted of low-cost and non-toxic elements of $\mathrm{Cu}, \mathrm{Sn}$ and $\mathrm{S}$, which have been reported to play a vital role in regulating the metabolic activity in skin pigmentation, tissue repairs, and acting as building blocks of proteins and tissues ${ }^{[21,22]}$.

Herein, we presented a facile and low-cost fabrication procedure for $\mathrm{Cu}_{3} \mathrm{SnS}_{4}$ nanoflakes (NFs) and proposed a Vis-mediated photocatalytic and NIR-activated photothermal synergistic therapeutic strategy for combating the infections of both Gram-negative Escherichia coli (E. coli) and Gram-positive methicillin-resistant Staphylococcus aureus (MRSA) strains. The underlying antibacterial mechanism was carefully investigated and it was proposed that the ROS mediated cellular oxidative damage and NIR mediated photothermal disruption of bacterial membranes as well as physical contact collaboratively led to the advanced antibacterial therapy. A mouse skin defect and epidermal infected model were established in vivo, showing effective bacteria eradication and favorable healing effects with negligible biotoxicity. Moreover, the inherent localized surface plasmon resonance (LSPR) effect of $\mathrm{Cu}_{3} \mathrm{SnS}_{4} \mathrm{NFs}$ empowered them as an active substrate for surface-enhanced Raman scattering (SERS) imaging and SERS-labeled bacteria detection. Overall, the low cost and biocompatibility together with the solar-driven broad-spectrum photocatalytic/photothermal antibacterial property of $\mathrm{Cu}_{3} \mathrm{SnS}_{4} \mathrm{NFs}$ make them a 
candidate for sensitive bacteria detection and effective antibacterial treatment, showing great potential for future clinic applications.

\section{Results And Discussion}

\section{Construction and characterization of $\mathrm{Cu}_{3} \mathrm{SnS}_{4} \mathrm{NFs}$}

$\mathrm{Cu}_{3} \mathrm{SnS}_{4} \mathrm{NFs}$ were fabricated via a modified solvothermal procedure ${ }^{[23,24]}$. As shown in the transmission electron microscopy (TEM) images in Figure $1 \mathrm{~A}$, nearly monodispersed foliate $\mathrm{Cu}_{3} \mathrm{SnS}_{4} \mathrm{NFs}$ were produced. Notably, these NFs were built up by nanocrystals, as can be seen from the high-resolution TEM images and the selected area electron diffraction (SAED) pattern (Figure 1B, Figure S1 and S2). The element mappings in Figure $1 \mathrm{C}$ indicate that each element of $\mathrm{Cu}, \mathrm{Sn}$ and $\mathrm{S}$ was presented and distributed in the framework of $\mathrm{Cu}_{3} \mathrm{SnS}_{4} \mathrm{NFs}$ uniformly. The energy-disperse X-ray spectrum (EDS) shows the distribution of $\mathrm{Cu}, \mathrm{Sn}$ and $\mathrm{S}$ elements without the presence of any other impurities (Figure 1D). The atomic ratio of $\mathrm{Cu}: \mathrm{Sn}: \mathrm{S}$ is about 2.4:1:3.26, indicating $\mathrm{Cu}$ and $\mathrm{S}$ vacancies compared with the stoichiometric ratio of $\mathrm{Cu}_{3} \mathrm{SnS}_{4}$. The crystal structure of as-prepared $\mathrm{Cu}_{3} \mathrm{SnS}_{4} \mathrm{NFs}$ was further characterized by X-ray diffraction (XRD). As shown in Figure 1E, the diffraction peaks at $2 \theta$ values of $28.5,47.5$, and 56.0 were assigned to the (112), (220) and (132) crystal planes of tetragonal $\mathrm{Cu}_{3} \mathrm{SnS}_{4}$ (JCPDS card No. 33-0501). No impurities can be found in the XRD pattern, indicating the pure phase of $\mathrm{Cu}_{3} \mathrm{SnS}_{4}$ without secondary phases. The zeta potential analysis shows that the surface of $\mathrm{Cu}_{3} \mathrm{SnS}_{4} \mathrm{NFs}$ was positively charged $(+6.3 \mathrm{mV})$ in deionized water (Figure 1F). X-ray photoelectron spectroscopy (XPS) was used to further explore the oxidation state of $\mathrm{Cu}, \mathrm{Sn}$ and $\mathrm{S}$ elements in the $\mathrm{Cu}_{3} \mathrm{SnS}_{4}$. The XPS survey spectrum reveals the presence of $\mathrm{Cu}, \mathrm{Sn}$ and $\mathrm{S}$ peaks (Figure S3). The binding energies of the $\mathrm{Cu}_{2} \mathrm{p}_{3 / 2}$ and Cu2 $\mathrm{p}_{1 / 2}$ centered at $932.1 \mathrm{eV}$ and $952.1 \mathrm{eV}$ respectively (Figure $1 \mathrm{G} 1$ ), which could be typically assigned to $\mathrm{Cu}^{+}$species $^{[25]}$. Additionally, the $\mathrm{Cu}_{2} \mathrm{p}_{3 / 2}$ satellite peak at $942.8 \mathrm{eV}$ could be identified as $\mathrm{Cu}^{2+}$ species ${ }^{[25]}$, suggesting the presence of both $\mathrm{Cu}^{+}$and $\mathrm{Cu}^{2+}$ species in the $\mathrm{Cu}_{3} \mathrm{SnS}_{4} \mathrm{NFs}$. The binding energies of the $\mathrm{Sn}_{3} \mathrm{~d}_{5 / 2}$ and $\mathrm{Sn} 3 \mathrm{~d}_{3 / 2}$ centered at $486.8 \mathrm{eV}$ and $495.2 \mathrm{eV}$ respectively (Figure 1G2), corresponding to the reported values for $\mathrm{Sn}^{4+[26]}$. No evidence of $\mathrm{Sn}^{2+}$ (binding energy at $485.2 \mathrm{eV}$ ) was detected in the sample. The S2p core-level spectrum indicated the binding energy at $161.9 \mathrm{eV}$ (Figure 1G3). Additional peak at $168.9 \mathrm{eV}$ was also detected, which may be attributed to the oxidized parts of the product.

\section{The photocatalysis mediated ROS generation from $\mathrm{Cu}_{3} \mathrm{SnS}_{4}$ NFs}

As shown in Figure 2A, the typical optical absorption range of $\mathrm{Cu}_{3} \mathrm{SnS}_{4} \mathrm{NFs}$ crosses from the UV to NIR region (250-1000 nm), highly desirable for full spectrum solar-driven photocatalysis and photothermal antibacterial treatment. The visible light mediated photocatalytic ROS generation was initially evaluated 
by methylene blue (MB) degradation kinetics, which was monitored by an UV/Vis spectrophotometer. Under visible light irradiation, time-dependent decolorization of MB was observed after incubation with $\mathrm{Cu}_{3} \mathrm{SnS}_{4} \mathrm{NFs}$ for different times (Figure 2B). The degradation of MB was confirmed by its characteristic absorbance at $664 \mathrm{~nm}$, which decreased with the reaction proceeding (Figure 2C). Since both $\mathrm{Cu}^{+}$and $\mathrm{Cu}^{2+}$ are presented in the $\mathrm{Cu}_{3} \mathrm{SnS}_{4} \mathrm{NFs}$, it was expected that the $\mathrm{Cu}$ ions mediated Fenton-like reaction may boost the ROS generation and further exacerbate the degradation of $\mathrm{MB}^{[27]}$. As observed, the adding of tiny $\mathrm{H}_{2} \mathrm{O}_{2}(1 \mathrm{mM})$ into the reaction mixture greatly improved the time-dependent degradation efficiency (Figure 2D, E). It was noted that almost no degradation of $\mathrm{MB}$ occurred in $1 \mathrm{mM} \mathrm{H}_{2} \mathrm{O}_{2}$ solution without the $\mathrm{Cu}_{3} \mathrm{SnS}_{4}$ catalyst, demonstrating the photocatalysis mediated generation of ROS and degradation of MB. In advanced oxidation technologies, hydroxyl radicals $(\cdot \mathrm{OH})$ are known as one of the key active species for MB degradation with a redox potential of $+2.8 \mathrm{~V}$ (versus NHE) in acidic media and $+1.5 \mathrm{~V}$ (versus $\mathrm{NHE}$ ) in basic media ${ }^{[28]}$. To test whether $\cdot \mathrm{OH}$ was generated during the $\mathrm{Cu}_{3} \mathrm{SnS}_{4}$ mediated photocatalytic process, $t$-butanol $(t-\mathrm{BuOH})$, a powerful $\cdot \mathrm{OH}$ scavenger ${ }^{[29]}$, was pre-added to the reaction mixture to investigate whether the degradation could be retarded. It was found that the adding of $t-\mathrm{BuOH}$ resulted in a concentration-dependent decrease of the MB degradation but not completely quench the reaction (Figure 2F and Figure S4). It is reasonable to speculate that other radical species may be involved in the MB degradation. Here, sodium azide $\left(\mathrm{NaN}_{3}, 5 \mathrm{mM}\right)$, a well-known scavenger for the singlet oxygen $\left({ }^{1} \mathrm{O}_{2}\right)$ $[30,31]$, was pre-added to the reaction mixture. As expected, the MB degradation was significantly restrained in the presence of $\mathrm{NaN}_{3}$, suggesting the involvement of ${ }^{1} \mathrm{O}_{2}$ in the $\mathrm{Cu}_{3} \mathrm{SnS}_{4}$ mediated $\mathrm{MB}$ degradation (Figure $2 \mathrm{~F})$. Similarly, the adding of benzoquinone $(1 \mathrm{mM})$, a scavenger of the superoxide radical $\left(\mathrm{O}_{2}^{-{ }^{-}}\right)^{[32]}$, also greatly alleviated the $\mathrm{MB}$ degradation, indicating the occurrence of $\mathrm{O}_{2}{ }^{--}$in the degradation. These data revealed that $\cdot \mathrm{OH}^{1}{ }^{1} \mathrm{O}_{2}$, and $\mathrm{O}_{2}{ }^{-\cdots}$ possibly occurred and participated in the $\mathrm{MB}$ degradation process. In addition, to directly prove the $\mathrm{Cu}_{3} \mathrm{SnS}_{4}$ mediated ROS generation, the content of $\cdot \mathrm{OH},{ }^{1} \mathrm{O}_{2}$, and $\mathrm{O}_{2}{ }^{\cdot-}$ was detected by electron paramagnetic resonance (EPR) using DMPO (5,5-dimethyl-1pyrroline $N$-oxide) and TEMPO (2,2,6,6-tetramethylpiperidine-1-oxyl) as spin probes ${ }^{[33]}$. As demonstrated

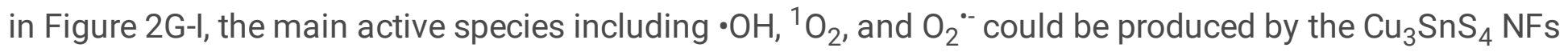
under visible light irradiation. Importantly, the amount of $\cdot \mathrm{OH},{ }^{1} \mathrm{O}_{2}$, and $\mathrm{O}_{2}{ }^{*-}$ all gradually increased with the prolonged irradiation time. These ROS may further attack bacteria around the photocatalyst and contribute to efficient antibacterial treatment.

\section{The NIR mediated hyperthermia of $\mathrm{Cu}_{3} \mathrm{SnS}_{4} \mathrm{NFs}$}

$\mathrm{Cu}_{3} \mathrm{SnS}_{4}$ possesses obvious localized surface plasmon resonances (LSPR) in the NIR band ${ }^{[23,34]}$. It was speculated that the strong NIR absorption of $\mathrm{Cu}_{3} \mathrm{SnS}_{4} \mathrm{NFs}$ observed in this work could be attributed to LSPR, which may further lead to photothermal effect for antibacterial treatment. Here, different concentrations of $\mathrm{Cu}_{3} \mathrm{SnS}_{4} \mathrm{NFs}$ were dispersed in aqueous solutions and exposed to an $808 \mathrm{~nm}$ NIR laser irradiation for different times. Figure $3 \mathrm{~A}-\mathrm{C}$ clearly displays the concentration and irradiation time- 
dependent photothermal conversion of $\mathrm{Cu}_{3} \mathrm{SnS}_{4} \mathrm{NFs}$. The solution temperature was precisely controlled between $25^{\circ} \mathrm{C}$ and $52^{\circ} \mathrm{C}$ by varying the $\mathrm{Cu}_{3} \mathrm{SnS}_{4}$ concentration or the irradiation time of the NIR light. In contrast, the temperature change of pure water was less than $2{ }^{\circ} \mathrm{C}$ under otherwise identical experimental conditions. Importantly, the photothermal conversion of $\mathrm{Cu}_{3} \mathrm{SnS}_{4} \mathrm{NFs}$ was also found to be laser power density-dependent, showing distinct temperature increase when promoting the laser power density from 0 $\mathrm{W} \mathrm{cm}{ }^{-2}$ to $2.5 \mathrm{~W} \mathrm{~cm}^{-2}$ (Figure 3D, E). Nine successive cycles of heating/cooling processes demonstrated the stable photothermal conversion capability, which is of key importance for photothermal agents during photothermal treatment (Figure 3F). The photothermal conversion efficiency of $\mathrm{Cu}_{3} \mathrm{SnS}_{4} \mathrm{NFs}$ was calculated to be $55.7 \%$ (Figure 3G, H). The $\mathrm{Cu}$ ions released from the $\mathrm{Cu}_{3} \mathrm{SnS}_{4} \mathrm{NFs}$ were evaluated by inductively coupled plasma optical emission spectrometry (ICP-OES). $5.1 \%$ of Cu ions was released from the $\mathrm{Cu}_{3} \mathrm{SnS}_{4} \mathrm{NFs}$ within $24 \mathrm{~h}$ and $5.8 \%$ within $48 \mathrm{~h}$ in PBS (pH 7.4), respectively (Figure 3l). Besides, it was found that the NIR irradiation ( $808 \mathrm{~nm}, 2 \mathrm{~W} \mathrm{~cm}^{-2}, 10 \mathrm{~min}$ ) did not show distinct interference on the release of $\mathrm{Cu}$ ions.

\section{In vitro antibacterial activity}

Considering the excellent properties of $\mathrm{Cu}_{3} \mathrm{SnS}_{4} \mathrm{NFs}$ as described above, we set out to examine the possibility of the NFs as a potential photocatalytic agent in combination with the photothermal performance for synergistic elimination of bacteria. Here, the synergistic antibacterial activities of $\mathrm{Cu}_{3} \mathrm{SnS}_{4} \mathrm{NFs}$ against both Gram-negative and Gram-positive bacteria were evaluated using $E$. coli and MRSA as model strains, respectively. The relative bacterial cells survival was calculated and the colony forming unit (CFU) plate counting method was used to assess the photo-activated disinfection ability of $\mathrm{Cu}_{3} \mathrm{SnS}_{4} \mathrm{NFs}$ (Figure S5). As shown in Figure 4A and Figure S6, both bacteria of E. coli and MRSA did not show apparent response to only visible light treatment in the absence of the $\mathrm{Cu}_{3} \mathrm{SnS}_{4} \mathrm{NFs}$ and the cell survival was accordingly used as the control group (Group I). In contrast, the bacterial cells survival dramatically decreased to $46.8 \%$ (E. coli) and $24.1 \%$ (MRSA) after treating with $\mathrm{Cu}_{3} \mathrm{SnS}_{4}$ at the concentration of $50 \mathrm{mg} \mathrm{mL}^{-1}$ under visible light for $20 \mathrm{~min}$ (Group III), demonstrating the $\mathrm{Cu}_{3} \mathrm{SnS}_{4} \mathrm{NFs}$ mediated inactivation of both bacteria strains. Notably, the bacterial cells survival further decreased to $22.8 \%$ (E. coli) and 16.5\% (MRSA) after the $\mathrm{Cu}_{3} \mathrm{SnS}_{4}$ plus $808 \mathrm{~nm}$ NIR treatment (10 min) under otherwise identical conditions (Group IV). Since NIR alone (Group II, $808 \mathrm{~nm}, 1.5 \mathrm{~W} \mathrm{~cm}^{-2}, 10 \mathrm{~min}$ ) did not show any antibacterial effect against both strains (Figure S7), the enhanced antibacterial effect after the $\mathrm{Cu}_{3} \mathrm{SnS}_{4}$ plus NIR treatment thus could be attributed to the NIR activated and synergistic photothermal effect of $\mathrm{Cu}_{3} \mathrm{SnS}_{4}$. Moreover, the photo-activated disinfection activity of $\mathrm{Cu}_{3} \mathrm{SnS}_{4} \mathrm{NFs}$ could be further enhanced by increasing the dose of the NFs (Figure 4A). The bacterial cells survival further decreased to $36.4 \%$ for E. coli and $19.6 \%$ for MRSA when promoting the $\mathrm{Cu}_{3} \mathrm{SnS}_{4} \mathrm{NFs}$ dose to $100 \mu \mathrm{g} \mathrm{mL}^{-1}$. The CFU plate counting provides a more intuitive characterization of the disinfection ability of $\mathrm{Cu}_{3} \mathrm{SnS}_{4} \mathrm{NFs}$ (Figure 4B, C). The antibacterial results under only NIR laser irradiation (group II) was almost the same as that in the control group (group I). In contrast, with the $\mathrm{Cu}_{3} \mathrm{SnS}_{4} \mathrm{NFs}$ treatment, a drastic decrease of MRSA colonies 
was observed and even no E. coli colonies could be detected under only visible light irradiation for 20 min (group III). More significant disinfection efficiency and complete inhibition of bacterial growth were detected in both bacterial models after the $\mathrm{Cu}_{3} \mathrm{SnS}_{4} \mathrm{NFs}$ plus NIR treatment (group IV), demonstrating the remarkable antibacterial ability of photo-activated $\mathrm{Cu}_{3} \mathrm{SnS}_{4} \mathrm{NFs}$ (Figure $4 \mathrm{~B}, \mathrm{C}$ ). The tiny $\mathrm{Cu}$ ions released from the $\mathrm{Cu}_{3} \mathrm{SnS}_{4} \mathrm{NFs}$ were found to play a negligible role on the antibacterial activity of the NFs, as verified by the extract liquid results (Figure S8). Fluorescence staining of live/dead cells was performed to further verify the feasibility of eliminating bacteria with different treatments. As shown in the confocal laser scanning microscopy (CLSM) images in Figure 4D, compared with the green fluorescence displayed in both the control group (group I) and the NIR group (group II), a number of dead cells (red fluorescence) were clearly detected in both strains after incubation with $\mathrm{Cu}_{3} \mathrm{SnS}_{4} \mathrm{NFs}$ even without laser irradiation (group III), which was consistent with the bacterial cell survival results. As expected, treatment with $\mathrm{Cu}_{3} \mathrm{SnS}_{4} \mathrm{NFs}$ plus NIR irradiation induced almost complete death of both bacterial cells, indicating their synergistic and stronger cell-killing effect (group IV).

In this study, we rationalized the efficient antimicrobial activity of $\mathrm{Cu}_{3} \mathrm{SnS}_{4} \mathrm{NFs}$ on the basis of the photocatalysis-mediated ROS generation, which further induced the oxidative stress to kill bacterial cells. To highlight this property, the ROS level in MRSA bacterial cells were explored by 2',7'dichlorodihydrofluorescein diacetate (DCFH-DA) staining, which acts as a commonly used method to evaluate the overall oxidative stress level in cells. As exhibited in Figure $5 \mathrm{~A}$ and Figure $\mathrm{S} 9$, bacteria treated with $\mathrm{Cu}_{3} \mathrm{SnS}_{4} \mathrm{NFs}$ with or without NIR irradiation displayed an elevated level of intracellular ROS, which may contribute to the observed antibacterial efficacy of $\mathrm{Cu}_{3} \mathrm{SnS}_{4} \mathrm{NFs}$. Since both $\mathrm{Cu}^{+}$and $\mathrm{Cu}^{2+}$ are presented in the $\mathrm{Cu}_{3} \mathrm{SnS}_{4} \mathrm{NFs}$, it was expected that the $\mathrm{Cu}$ ions mediated Fenton-like reaction together with the visible light mediated photocatalysis may collaboratively result in the ROS overproduction (Figure 5B). To further investigate the antibacterial mechanism of photo-activated $\mathrm{Cu}_{3} \mathrm{SnS}_{4} \mathrm{NFs}$, the cell morphologies of both E. coli and MRSA following different treatments were studied by scanning electron microscopy (SEM, Figure 5C). Indeed, in contrast to the well-maintained cell morphology in the control group (group I) and NIR group (group II), distorted cell morphology with lesions and holes on the bacterial cell wall/membranes were observed in both bacterial strains after treatment with $\mathrm{Cu}_{3} \mathrm{SnS}_{4} \mathrm{NFs}$ with or without NIR irradiation (group III and group IV). The photogenerated ROS and hyperthermia were presumed to contribute to the cell membrane damage jointly. Besides, a mass of NFs were discovered on the surface of bacteria. Since the surface of bacteria are commonly negatively charged due to the presence of teichoic acids in the cell wall of Gram-positive bacteria and lipopolysaccharide in the outer membrane of Gram-negative bacteria ${ }^{[15]}$, it could be speculated that the electrostatic interaction between the positively charged NFs and the negatively charged bacteria would facilitate the preferential absorption (physical contact) of NFs and reinforce the photocatalysis-based antibacterial efficacy by compromising bacterial membrane integrity ${ }^{[5]}$ (Figure 5D).

\section{In Vivo Antibacterial Activity}


The in vitro biocompatibility of as-prepared $\mathrm{Cu}_{3} \mathrm{SnS}_{4} \mathrm{NFs}$ was evaluated prior to their in vivo biomedical applications. The cytotoxicity of $\mathrm{Cu}_{3} \mathrm{SnS}_{4} \mathrm{NFs}$ to human umbilical vein endothelial cells (HUVEC) and mouse skin fibroblast L929 cells were evaluated, showing no significant toxicity in the wide concentration range of $10-100 \mu \mathrm{g} \mathrm{mL}^{-1}$ within $24 \mathrm{~h}$ and $48 \mathrm{~h}$ (Figure S10). To assess the in vivo antibacterial efficacy of $\mathrm{Cu}_{3} \mathrm{SnS}_{4} \mathrm{NFs}$, ICR mice with a MRSA-infected cutaneous wound model were fabricated. Initially, the in vivo photothermal effect was explored and shown in Figure 6A. In contrast to the control group, which showed no distinct change of temperature in the wound area of mice $\left(33.8^{\circ} \mathrm{C}\right.$ after $10 \mathrm{~min}$ of laser treatment), significantly increased temperature was found in the wound area of the mice treated with $\mathrm{Cu}_{3} \mathrm{SnS}_{4} \mathrm{NFs}$ under the NIR laser irradiation. To be noted, the temperature in the wound area was irradiation time-dependent, which could rapidly reach $49.2^{\circ} \mathrm{C}$ in 2 min and maintain around $50{ }^{\circ} \mathrm{C}$ in the following 8 min (Figure 6B). Despite the hyperthermia, no obvious normal tissue damage was observed due to the specific and focused laser irradiation toward the wound area. Then, the photo-activated skin wound-healing ability of $\mathrm{Cu}_{3} \mathrm{SnS}_{4} \mathrm{NFs}$ in wound-infecting mice was evaluated. The treatment process is shown in Figure 6C. A rounded cutaneous wound model ( $6 \mathrm{~mm}$ in diameter) was constructed in male ICR mice. Then, MRSA, a common cause of skin infections, was used to construct the wound infecting model. Afterwards, the MRSA-infected mice were divided into four groups ( $n=6$ for each group) and treated with i) PBS (control group), ii) PBS followed by $808 \mathrm{~nm}$ NIR laser irradiation (NIR group), iii) $\mathrm{Cu}_{3} \mathrm{SnS}_{4}$ dispersed in PBS ( $\mathrm{Cu}_{3} \mathrm{SnS}_{4}$ group), iv) $\mathrm{Cu}_{3} \mathrm{SnS}_{4}$ dispersed in PBS followed by $808 \mathrm{~nm}$ NIR laser irradiation $\left(\mathrm{Cu}_{3} \mathrm{SnS}_{4}+\mathrm{NIR}\right.$ group), respectively. Mice in all groups were exposed to visible light during the treatment. The size of the wound and weight of each mouse were recorded every two days. As shown in Figure 6D, mice treated with PBS or NIR alone did not show distinct healing of wound despite the presence of scars in both groups (control and NIR group). Significantly, the wound area of mice treated with $\mathrm{Cu}_{3} \mathrm{SnS}_{4}$ $\left(\mathrm{Cu}_{3} \mathrm{SnS}_{4}\right.$ group) was generally smaller, showing around $93.5 \%$ recovery on day 8 (Figure 6E). More importantly, mice treated with $\mathrm{Cu}_{3} \mathrm{SnS}_{4}$ plus NIR irradiation $\left(\mathrm{Cu}_{3} \mathrm{SnS}_{4}+\mathrm{NIR}\right.$ group) displayed more pronounced recovery of wound. The trauma area on day 4 has exhibited significant difference as compared to the $\mathrm{Cu}_{3} \mathrm{SnS}_{4}$ group ( ${ }^{*} p<0.05$, Figure $\left.6 \mathrm{E}\right)$, demonstrating the promoted antibacterial and wound healing efficiency based on the collaborative photocatalytic and photothermal antibacterial effects. To further investigate the wound healing process, the wound skin in each group was harvested and exposed to Hematoxylin and eosin (H\&E) staining after the treatment. As shown in Figure 6F, the wound boundary between the wound and normal tissue could be observed clearly from the histological staining results. The keratinocytes migrated to the wound area from the normal tissue and scars became significantly smaller and even vanished after the treatment with $\mathrm{Cu}_{3} \mathrm{SnS}_{4} \mathrm{NFs}$ or $\mathrm{Cu}_{3} \mathrm{SnS}_{4} \mathrm{NFs}$ plus NIR irradiation, whereas incomplete dermal layer was still observed in the control and NIR groups. Besides, the histological slices of both the control group and NIR group presented a number of inflammatory cells, predominantly neutrophils and mononuclear cells adhered to the stratified squamous epithelium. In contrast, intact epidermal layer accompanied with dramatic decrease of the infiltration of inflammatory cells was found after the treatment with $\mathrm{Cu}_{3} \mathrm{SnS}_{4}$ or $\mathrm{Cu}_{3} \mathrm{SnS}_{4}$ plus NIR irradiation, further indicating the efficiency of the photo-activated antibacterial effect of the $\mathrm{Cu}_{3} \mathrm{SnS}_{4} \mathrm{NFs}$. 


\section{In vivo evaluation of collagen deposition and angiogenesis in wounds}

Wound healing is a dynamic process that involves the proliferation of fibroblasts, deposition of collagen fibers, angiogenesis, formation of granulation tissue, scar formation, wound contraction and epithelialization ${ }^{[36]}$. The synthesis and deposition of collagen is a critical factor in wound healing. $\mathrm{Cu}$ ions have been recognized as a cofactor to lysyl oxidase, which stimulates the expression of matrix metalloproteinase-2 and collagen in fibroblasts, facilitating wound healing ${ }^{[37-39]}$. Histological analysis of Masson's trichrome stained sections showed extensive collagen deposition and a smaller granulation tissue gap in the wounds after the treatment with $\mathrm{Cu}_{3} \mathrm{SnS}_{4}$ (Figure 7A, B). Importantly, more wavy collagen fibers were observed in the wounds of the $\mathrm{Cu}_{3} \mathrm{SnS}_{4}+\mathrm{NIR}$ group, demonstrating the favourable extracellular matrix remodeling of granulation tissue and regeneration of the epidermis ${ }^{[40]}$. Further, immunofluorescence staining for CD31, a transmembrane protein expressed early in vascular development, was used to evaluate the newly formed vessels ${ }^{[41]}$. It showed that the density of newly formed vessels in the wounds of the $\mathrm{Cu}_{3} \mathrm{SnS}_{4}$ and $\mathrm{Cu}_{3} \mathrm{SnS}_{4}+$ NIR group was more significant compared with the other two groups (Figure 7C). The Western blot analysis of CD31 was in concordance with the immunofluorescence staining results, further confirming the promoted vessel number after the treatments (Figure 7D). Moreover, it has been suggested that hypoxia plays a critical role in cell recruitment, cell differentiation and blood vessel formation ${ }^{[42]}$. Hypoxia inducible factor-1a (HIF-1a) has been identified to initiate the transcription of hypoxia sensitive genes including vascular endothelial growth factor (VEGF) under hypoxic conditions ${ }^{[43]}$. Stabilization and activation of HIF-1 a expression was thus suggested as a potential strategy to promote neovascularization ${ }^{[44]}$. The HIF-1 a expression and VEGF secretion in wounds after the treatment were then investigated, trying to figure out the angiogenesis during the wound healing process. The HIF-1a expression, as determined by the Western blot analysis, was promoted both in the $\mathrm{Cu}_{3} \mathrm{SnS}_{4}$ and $\mathrm{Cu}_{3} \mathrm{SnS}_{4}+\mathrm{NIR}$ group as compared with the other two groups (Figure 7D, E). Moreover, the immunofluorescence staining of VEGF showed more significant expression of VEGF and therefore more new blood vessel formation after the $\mathrm{Cu}_{3} \mathrm{SnS}_{4}$ and $\mathrm{Cu}_{3} \mathrm{SnS}_{4}+$ NIR treatment (Figure 7C). The promotion of angiogenesis was expected to allow more supply of oxygen and nutrients as well as accelerated migration of requisite cells and humoral factors into wounds, which leads subsequently to the increased formation of granulation tissue, collagen synthesis and eventually improved wound healing ${ }^{[38]}$.

Furthermore, the in vivo biosafety after the $\mathrm{Cu}_{3} \mathrm{SnS}_{4}$ and/or NIR treatment was evaluated. The body weight of mice in each group during the whole treatment process did not show distinct difference (Figure S11). Besides, the main blood biochemistry and hematology analyses of mice in each group after the treatment were conducted, suggesting normal functions in liver and kidney (Figure S12). The routine blood test was further assessed to monitor the systemic inflammatory activity, showing no significant differences as compared with the control group (Figure S13). Moreover, no visible damage, inflammation, or abnormality were observed in the histological evaluation of major organs including heart, liver, spleen, 
lung, and kidney (Figure 7F). Collectively, the biosafety analyses substantiate that the photo-activated antibacterial treatment showed no obvious side-effect to mice in vivo.

\section{$\mathrm{Cu}_{3} \mathrm{SnS}_{4} \mathrm{NFs}$ as an active SERS substrate for the detection of $E$. coli in vitro}

Surface-enhanced Raman scattering (SERS) imaging is a highly sensitive tool that allows direct identification of target analytes in proximity to the surface of plasmonic nanoparticles ${ }^{[45]}$. Due to its high sensitivity, chemical specific, high resolution, and non-destructive characteristics, SERS imaging has demonstrated applications in biomedicine as a promising tool for real-time bacteria detection ${ }^{[46]}$. $\mathrm{Cu}_{3} \mathrm{SnS}_{4}$ compound is a p-type semiconductor due to the presence of copper vacancies, which further endows $\mathrm{Cu}_{3} \mathrm{SnS}_{4}$ with localized surface plasmon resonance (LSPR) in the NIR region ${ }^{[47]}$. Indeed, a wide absorption band in the NIR region associated with LSPR is clearly observed in the UV/Vis/NIR spectrum of $\mathrm{Cu}_{3} \mathrm{SnS}_{4} \mathrm{NFs}$. The natural excitation of $\mathrm{Cu}_{3} \mathrm{SnS}_{4}$ LSPRs in the NIR paves the way for the employment of $\mathrm{Cu}_{3} \mathrm{SnS}_{4} \mathrm{NFs}$ as SERS substrate for enhanced signals of Raman imaging. Here, we set out to explore the possibility of utilizing $\mathrm{Cu}_{3} \mathrm{SnS}_{4} \mathrm{NFs}$ as a SERS substrate for the determination of bacteria content. E. coli was used as the model bacteria and tagged with Raman reporter molecules of 3,3'-diethylthiatricarbocyanine iodide (DTTC), followed by the immobilizing of $\mathrm{Cu}_{3} \mathrm{SnS}_{4} \mathrm{NFs}$ (designated as E. coli-DTTC-Cu $\mathrm{SnS}_{4}$ ). The as-prepared E. coli-DTTC-Cu $\mathrm{SnS}_{4}$ is illustrated in Figure 8A. The EDS analysis of the E. coli-DTTC- $\mathrm{Cu}_{3} \mathrm{SnS}_{4}$ showed well-merged element images of $\mathrm{C}, \mathrm{N}$, $\mathrm{O}, \mathrm{P}, \mathrm{Cu}, \mathrm{Sn}$, and S elements, confirming the presence of both DTTC and $\mathrm{Cu}_{3} \mathrm{SnS}_{4}$ on the bacteria. The $E$. coli-DTTC- $\mathrm{Cu}_{3} \mathrm{SnS}_{4}$ were subsequently exposed to a $785 \mathrm{~nm}$ laser with $10 \mathrm{~mW}$ laser power, $5 \mathrm{~s}$ acquisition time, and a 50xobject lens. Significant enhancement of characteristic Raman signals of the DTTC molecule around $507,621,784,848,1082,1134$, and $1248 \mathrm{~cm}^{-1}$ was observed after the coupling of $\mathrm{Cu}_{3} \mathrm{SnS}_{4} \mathrm{NFs}^{[48,49]}$, while negligible Raman signal was captured in equivalent $E$. coliDTTC without $\mathrm{Cu}_{3} \mathrm{SnS}_{4}$ nanostructure (Figure $8 \mathrm{C}$ ). This result clearly demonstrates the possibility of $\mathrm{Cu}_{3} \mathrm{SnS}_{4} \mathrm{NFs}$ as SERS substrate for the enhancement of Raman probe signals. As can be seen from the UV/Vis/NIR spectrum of E. coli-DTTC-Cu $\mathrm{SnS}_{4}$ (Figure 8D and Figure S14), the LSPR peak of E. coliDTTC- $\mathrm{Cu}_{3} \mathrm{SnS}_{4}$ was in proximity with the wavelength of the excitation laser for SERS imaging $(785 \mathrm{~nm})$. The enhancement thus could be attributed to the LSPR on the $\mathrm{Cu}_{3} \mathrm{SnS}_{4} \mathrm{NFs}$ under the excitation of 785 $\mathrm{nm}$ laser beam, which strengthened local electromagnetic field and led to enhanced Raman probe signals ${ }^{[50]}$. We subsequently demonstrate the high sensitivity of utilizing $\mathrm{Cu}_{3} \mathrm{SnS}_{4} \mathrm{NFs}$ for SERS based $E$. coli detection. A series of $E$. coli tagged with DTTC at concentrations from $10^{8} \mathrm{CFU} \mathrm{mL}^{-1}$ to $10^{3} \mathrm{CFU} \mathrm{mL}^{-1}$ were coupled with $\mathrm{Cu}_{3} \mathrm{SnS}_{4} \mathrm{NFs}$, followed by subjection to SERS detection. As shown in Figure $8 \mathrm{E}$ and Figure $\mathrm{S} 15$, the SERS labeled bacteria with different cell counts from $10^{8} \mathrm{CFU} \mathrm{mL}{ }^{-1}$ to $10^{4} \mathrm{CFU} \mathrm{mL}^{-1}$ could be clearly delineated with low signal-to-background ratio. Using the Raman shift of DTTC molecule at 507 $\mathrm{cm}^{-1}$ for detection, E. coli could be detected at a minimal concentration of $10^{4} \mathrm{CFU} \mathrm{mL}^{-1}$. Figure $8 \mathrm{~F}$ 
displays the intensity of the SERS peak at $507 \mathrm{~cm}^{-1}$ as a function of logarithmic concentrations of $E$. coliDTTC- $\mathrm{Cu}_{3} \mathrm{SnS}_{4}$. A linear dependence was found with concentrations of E. coli-DTTC- $\mathrm{Cu}_{3} \mathrm{SnS}_{4}$ ranging from $10^{4} \mathrm{CFU} \mathrm{mL}{ }^{-1}$ to $10^{8} \mathrm{CFU} \mathrm{mL}^{-1}$, corresponding to doses of $\mathrm{Cu}_{3} \mathrm{SnS}_{4}$ ranging from $75.5 \mu \mathrm{M}$ to 325.7 $\mu \mathrm{M}$ (Figure S16). Compared with commom noble metals ( $\mathrm{Ag}$ and $\mathrm{Au}$ ) nanostructure-based substrates, the fabrication procedure of Cu-based $\mathrm{Cu}_{3} \mathrm{SnS}_{4} \mathrm{NFs}$ is facile and low-cost, thus representing a promising active substrate for SERS based bacteria detection.

\section{Conclusions}

In conclusion, photo-activatable $\mathrm{Cu}_{3} \mathrm{SnS}_{4} \mathrm{NFs}$ were prepared for advanced antibacterial therapy by inducing efficient bacteria eradication and accelerated wound healing. The $\mathrm{Cu}_{3} \mathrm{SnS}_{4} \mathrm{NFs}$ could be activated by visible light, leading to effective overproduction of ROS in bacterial cells. Besides, the high photothermal conversion ef $\square$ ciency of $\mathrm{Cu}_{3} \mathrm{SnS}_{4} \mathrm{NFs}$ induced NIR light $(808 \mathrm{~nm})$ controlled hyperthermia in bacteria. Importantly, the electrostatic interaction between the positively charged $\mathrm{Cu}_{3} \mathrm{SnS}_{4} \mathrm{NFs}$ and the negatively charged bacteria facilitated the physical contact mediated bacteria killing. Consequently, the physical contact and ROS mediated cellular oxidative damage as well as the NIR mediated photothermal disruption of bacterial membranes played a synergistic role in the efficient eradication of both $E$. coli and MRSA in vitro and in vivo. On the other hand, the exogenous ions metabolism from the $\mathrm{Cu}_{3} \mathrm{SnS}_{4} \mathrm{NFs}$ significantly up-regulated the expression of HIF-1a, CD31 and VEGF, leading to increased formation of granulation tissue, collagen synthesis and eventually improved wound healing. Additionally, the $\mathrm{Cu}_{3} \mathrm{SnS}_{4}$ NFs can be used as an active SERS imaging substrate for SERS-labeled bacteria detection in vitro. The sensitive bacteria detection and the solar-driven broad-spectrum antibacterial therapeutic effects as well as the high biocompatibility and therapeutic biosafety endow $\mathrm{Cu}_{3} \mathrm{SnS}_{4} \mathrm{NFs}$ with potentiality for future clinical transformation.

\section{Methods}

\section{Materials}

\section{Reagents and kits}

Copper acetate hydrate $(\mathrm{CuAc} 2 \cdot \mathrm{H} 2 \mathrm{O})$, stannic chloride pentahydrate $(\mathrm{SnCl} 4 \cdot 5 \mathrm{H} 2 \mathrm{O})$, hydrogen peroxide ( $\mathrm{H} 2 \mathrm{O} 2,30 \mathrm{wt} \%$ ), thioacetamide (TAA), and N,N-dimethylformamide (DMF) were obtained from Sinopharm Chemical Reagent Co., Ltd. Sodium azide (NaN3), t-butanol (t-BuOH), benzoquinone, and methylene blue (MB) were purchased from Aladdin Chemical Reagent Co., Ltd. 5,5-dimethyl-1-pyrroline N-oxide (DMPO) and 2,2,6,6-tetramethylpiperidine-1-oxyl (TEMPO) were bought from Adamas Reagent, Ltd. All reagents were purchased as received and used without any further purification. 


\section{Preparation and characterization of Cu3SnS4 NFs}

The Cu3SnS4 NFs were prepared by a facile solvothermal strategy. In a typical synthesis, $0.06 \mathrm{mmol}$ CuAc2 $\cdot \mathrm{H} 2 \mathrm{O}, 0.04 \mathrm{mmol} \mathrm{SnCl} 4 \cdot 5 \mathrm{H} 2 \mathrm{O}$ and $0.08 \mathrm{mmol}$ thioacetamide (TAA) were mixed in $10 \mathrm{ml} \mathrm{N}, \mathrm{N}$ dimethylformamide (DMF). The mixture was purged with argon and stirred for $2 \mathrm{~h}$ under $140{ }^{\circ} \mathrm{C}$. Then, the reaction mixture was transferred to a stainless-steel autoclave and the reaction was processed at $220^{\circ} \mathrm{C}$ for $12 \mathrm{~h}$. After completing the reaction, the mixture was naturally cooled to room temperature and centrifuged at $5000 \mathrm{rpm}$ for $10 \mathrm{~min}$. The precipitate was washed with acetone and deionized water to remove by-products. The obtained black powder was dried at $80^{\circ} \mathrm{C}$ for $12 \mathrm{~h}$ and used for further characterization.

\section{Characterization}

Transmission electron microscopy (TEM), high resolution-TEM (HRTEM), energy dispersive X-ray spectroscopy (EDS), and the corresponding element mapping analyses were conducted on a JEM-2100F electron microscope. Zeta potential was determined on Malvern Zetasizer Nanoseries (Nano ZS90). X-ray photoelectron spectroscopy (XPS) was acquired on an Axis Ultra DLD spectrometer (Kratos, UK). UVvisible (UV/Vis) absorbance spectra were obtained on a UV-3101 Shimadzu spectroscope. The quantitative elemental analysis was carried out on an inductively coupled plasma optical emission spectrometer (ICP-OES, Agilent 700 Series, USA). Powder X-ray diffraction (XRD) pattern was tested on a Rigaku Ultima IV diffractometer. The electron paramagnetic resonance (EPR) was conducted on a Bruker EMXplus X-band EPR.

\section{The photocatalysis mediated ROS generation from Cu3SnS4 NFs}

The photocatalysis mediated ROS generation was evaluated using the methylene blue (MB) probe. Briefly, $4 \mathrm{~mL}$ of methylene blue (MB, $10 \mu \mathrm{g} \mathrm{mL}-1$ ) aqueous solution was added to $6 \mathrm{~mL}$ of the aqueous solution containing $0.6 \mathrm{mg}$ of Cu3SnS4 NFs and shaken slightly under light. $0.5 \mathrm{~mL}$ of the reaction suspension was then taken out, diluted with water, and detected by a UV/Vis spectrometer at $664 \mathrm{~nm}$ periodically. The MB degradation process was also photographed. To investigate the $\mathrm{Cu}$ ions mediated Fenton-like reaction, $1 \mathrm{~mL}$ of $\mathrm{H} 2 \mathrm{O} 2$ aqueous solution ( $1 \mathrm{mM}$ ) was immediately added to the above solution and the MB degradation was evaluated with a similar procedure.

Additionally, using DMPO and TEMPO as spin probes, the photocatalysis mediated ROS (including $\cdot \mathrm{OH}$, 102, and 02--) generation was further detected by electron paramagnetic resonance (EPR). Typically, 0.1 $\mathrm{mg}$ of Cu3SnS4 NFs were added to $10 \mathrm{~mL}$ of deionized water under dark conditions. The suspension was then exposed to visible light irradiation and the EPR signal of the complex of $\cdot \mathrm{OH}, 102$, and $02 \cdot$ - with the probes was captured periodically (0, 1 and $2 \mathrm{~min})$. 


\section{The NIR mediated hyperthermia of Cu3SnS4 NFs}

The NIR mediated hyperthermia and the photothermal efficiency of the Cu3SnS4 NFs were investigated using an $808 \mathrm{~nm}$ fiber-coupled laser system. Briefly, different concentrations of Cu3SnS4 dispersions ( 0 , $25,50,100,200$ and $400 \mu \mathrm{g} \mathrm{mL}-1)$ were irradiated by an $808 \mathrm{~nm}$ fiber-coupled laser system for different times $(0,2,4,6,8$ and $10 \mathrm{~min})$ at varied power density $(0,1,1.5,2$ and $2.5 \mathrm{~W} \mathrm{~cm}-2)$. The temperature of the suspensions was recorded every $50 \mathrm{sec}$ with an IR camera to analyze the temperature elevation tendency. The photothermal stability of Cu3SnS4 NFs was evaluated by turning on the NIR laser ( $808 \mathrm{~nm}$, $2.0 \mathrm{~W} \mathrm{~cm}-2$ ) for $10 \mathrm{~min}$ and then off until the dispersions reached room temperature periodically. Nine circulations were recorded.

The photothermal conversion efficiency $(\eta)$ was calculated using the following equations:

$$
\begin{gathered}
\eta=\frac{h S\left(T_{\text {Max }}-T_{\text {Surr }}\right)-Q_{\text {Dis }}}{I\left(1-10^{-A 808}\right)} \\
h s=\frac{m_{D} C_{D}}{\tau_{s}}
\end{gathered}
$$

In these equations, $\mathrm{mD}$ represents the solution mass and equals to $0.2 \mathrm{~g}$, while $\mathrm{cD}=4.2 \mathrm{~J} / \mathrm{g}$ is the heat capacity of water. TMAX $=42.15{ }^{\circ} \mathrm{C}$ and TSurr $=25^{\circ} \mathrm{C}$ are the maximum temperature of the NFs and the water during the irradiation process, resectively. QDis is associated with the light absorbance of the solvent, which approximately equals to 0 . $\tau$ is is the irradiation time during the temperature rise and equals

to $195.5 \mathrm{~s}$. I is the laser power and equals to $2.0 \mathrm{~W} \mathrm{~cm}-2$. A808 $=0.47$ is the absorbance of the NFs at 808 $\mathrm{nm}$. The photothermal conversion efficiency was thus calculated to be $55.7 \%$.

The $\mathrm{Cu}$ ions released from the Cu3SnS4 NFs were investigated by ICP-OES analysis. Typically, $0.5 \mathrm{mg}$ of Cu3SnS4 NFs were added to $10 \mathrm{~mL}$ of deionized under dark conditions at room temperature. The $\mathrm{Cu}$ ions release process was performed on a shaking table at a shaking speed of $180 \mathrm{rpm}$. At each time point, 1 $\mathrm{mL}$ of the supernate was taken out, filtrated, diluted, and measured by ICP-OES. To investigate the NIR mediated $\mathrm{Cu}$ ions release, the suspension was exposed to NIR irradiation (808 nm, $2.0 \mathrm{~W} \mathrm{~cm}-2)$ for 10 $\min$.

\section{In vitro cytotoxicity of Cu3SnS4 NFs}

Human umbilical vein endothelial cells (HUVECs) and mouse fibroblast cells (L929) were obtained from the China Center of Industrial Culture Collection. Cells were seeded separately into 96 -well plates at $1 \times$ 106 cells $\mathrm{mL}-1$. The cells were incubated in a-MEM with $10 \% \mathrm{FBS}$ at $37^{\circ} \mathrm{C}$ in $5 \% \mathrm{CO} 2$ atmosphere. After $24 \mathrm{~h}$, the original media was removed, and a-MEM containing a diverse concentration of Cu3SnS4 NFs ( 0 , $10,25,50,100 \mu \mathrm{g} \mathrm{mL}-1)$ was added to the plates. Cytotoxicity was detected after $24 \mathrm{~h}$ and $48 \mathrm{~h}$ co-culture using the MTT method. All wells to be detected were washed with PBS for three times, after which MTT 
solution ( $100 \mu \mathrm{L}, 0.5 \mathrm{mg} \mathrm{mL}-1)$ was added to each well and further incubated for $4 \mathrm{~h}$ at $37^{\circ} \mathrm{C}$. The optical density (OD) of each solution was tested at $492 \mathrm{~nm}$ using an ELX-800 absorbance microplate reader.

\section{In vitro bacterial cell culture}

Gram-negative E. Coli (ATCC 25922) and Gram-positive methicillin-resistant S. aureus (MRSA, ATCC 43300) were obtained from American Type Culture Collection(ATCC). E. coli (ATCC 25922) and MRSA (ATCC 43300) were initially seeded on solid Luria-Bertani Broth medium with streak plate method. After being cultured at $36^{\circ} \mathrm{C}$ for $24 \mathrm{~h}$, we collected a single bacterial colony and immerged it into $10 \mathrm{~mL}$ of liquid Luria-Bertani Broth medium separately for further cultivation. The centrifuge tubes were placed in a shaking incubator at $100 \mathrm{rpm}$ at $30^{\circ} \mathrm{C}$ for $20 \mathrm{~h}$. Cells were then centrifuged $\left(5000 \mathrm{rpm}, 10 \mathrm{~min}, 4^{\circ} \mathrm{C}\right.$ ) and washed with PBS for three times before use.

\section{The evaluation of antibacterial activity of Cu3SnS4 NFs in Vitro}

The antibacterial probability of Cu3SnS4 NFs was measured with the spread plate method. The solution was concentrated using a centrifuge $\left(5000 \mathrm{rpm}, 10 \mathrm{~min}, 4^{\circ} \mathrm{C}\right)$ and the supernatant was removed. Next, the pellets were resuspended and diluted at a density of $1 \times 105 \mathrm{CFU} \mathrm{mL-1}$ with PBS (pH 6.0) containing Cu3SnS4 NFs at $100 \mu \mathrm{g} \mathrm{mL}-1$ and $0 \mu \mathrm{g} \mathrm{mL-1}$, according to the optical density (OD) value tested at 650 $\mathrm{nm}$. Each concentration of solution underwent various disposal: I. Control: A suspension containing $0 \mu \mathrm{g}$ $\mathrm{mL}-1$ of Cu3SnS4 NFs, irradiated with steady light. II. A suspension containing $0 \mu \mathrm{g} \mathrm{mL}-1$ of Cu3SnS4

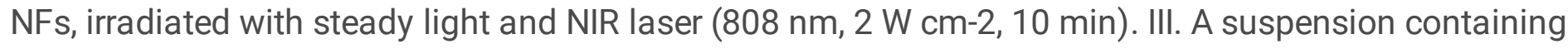
$100 \mu \mathrm{g} \mathrm{mL}-1$ of Cu3SnS4 NFs, irradiated with steady light. IV: A suspension containing $100 \mu \mathrm{g} \mathrm{mL}-1$ of Cu3SnS4 NFs, irradiated with steady light and NIR laser (808 nm, $2 \mathrm{~W} \mathrm{~cm}-2,10 \mathrm{~min})$. After the procedure, $100 \mu \mathrm{l}$ of each diluted suspension was spread onto the solid Luria-Bertani Broth medium, incubated at 37 ${ }^{\circ} \mathrm{C}$ in $5 \% \mathrm{CO} 2$ overnight. The number of bacterial colonies was then counted.

\section{In vitro fluorescence live/dead staining of bacteria}

The bacterial suspensions were prepared in different methods : I. PBS. II. PBS + NIR laser $(808 \mathrm{~nm}, 2 \mathrm{~W}$ cm-2, $10 \mathrm{~min})$. III. Cu3SnS4 NFs (100 $\mu \mathrm{g} \mathrm{mL-1).} \mathrm{IV.} \mathrm{Cu3SnS4} \mathrm{NFs} \mathrm{(100} \mathrm{\mu g} \mathrm{mL-1)} \mathrm{+} \mathrm{NIR} \mathrm{laser} \mathrm{(808} \mathrm{nm,} 2 \mathrm{~W}$ $\mathrm{cm}-2,10 \mathrm{~min}$ ). Before staining, the supernatant containing bacterial cells was collected and centrifuged to remove Cu3SnS4 NFs. The supernatant was also discarded to remove nucleic acids or other media components that might decrease staining efficiency. Then we resuspended the pellets with sterile water containing $0.85 \% \mathrm{NaCl}$, SYTO9 $(10 \mu \mathrm{M})$ and PI $(10 \mu \mathrm{M})$. The suspension was incubated in the dark for 15 min. The stained cells were transferred to confocal dishes. Fluorescent images of the live (green fluorescent) and dead (red fluorescent) cells were obtained using an Olympus confocal laser scanning microscope. 


\section{Morphology observation of bacteria by bio-SEM}

After the anti-bacteria test, cell morphology images were acquired by SEM scanning. The bacterial suspensions: I. PBS. II. PBS + NIR laser (808 nm, 2 W cm-2, 10 min). III. Cu3SnS4 NFs (100 $\mu \mathrm{g} \mathrm{mL-1).} \mathrm{IV.}$ Cu3SnS4 NFs (100 $\mu \mathrm{g} \mathrm{mL}-1)+$ NIR laser $(808 \mathrm{~nm}, 2 \mathrm{~W} \mathrm{~cm}-2,10 \mathrm{~min})$ were fixed with $2.5 \%$ glutaraldehyde overnight at $4{ }^{\circ} \mathrm{C}$. All samples were centrifuged and resuspended with PB $(0.1 \mathrm{M})$ for four times. Then all samples were fixed with osmic acid (1\%, pH 7.3) for 1 hour. Before dehydration, samples were washed with PB (0.1 M) and ultrapure water for 2 times. Graded alcohol $(30 \%, 50 \%, 60 \%, 70 \%, 80 \%, 90 \%, 100$ $\%, 100 \%$, and $100 \%$ ) was applied to dehydrate the bacteria. During each procedure, the pellets were mixed with solution thoroughly for 10 minutes. All samples were dried using the supercritical $\mathrm{CO} 2$ drying technology. The bacteria morphology was visualized using bio-SEM.

\section{Animals}

Male ICR mice aged 5 weeks were obtained from Shanghai Super - B\&K laboratory animal Corp. Ltd. The Institutional Animal Care and Use Committee of Shanghai Ninth People's Hospital, Shanghai Jiao Tong University School of Medicine approved all the animal study protocols. All animal experiments were carried out in agreement with the guidelines of Shanghai Laboratory Animal Research Center.

\section{In vivo wound disinfection and healing assay}

The ICR mice were divided into four groups, and each group consists of four mice. All mice were raised in cages under the same condition. First, the mice were injected with $5 \%$ chloral hydrate in the abdominal cavity. After anesthesia took effect, a circular wound in $6 \mathrm{~mm}$ was prepared on the back of each mouse with a skin punch. One day after the wound was created, $50 \mu \mathrm{L}$ of MRSA solution $(2 \times 108 \mathrm{CFU} \mathrm{mL}-1)$ was dropped into each wound to construct the wound healing model. According to the grouping, various treatments were operated: I. PBS. II. PBS + NIR laser (808 nm, $1.0 \mathrm{~W} \mathrm{cm-2,10} \mathrm{min).} \mathrm{III.} \mathrm{Cu3SnS4} \mathrm{NFs} \mathrm{(100}$ $\mu \mathrm{g} \mathrm{mL}-1)$. IV. Cu3SnS4 NFs (100 $\mu \mathrm{g} \mathrm{mL-1)} \mathrm{+} \mathrm{NIR} \mathrm{laser} \mathrm{(808} \mathrm{nm,} 1.0 \mathrm{~W} \mathrm{cm-2,10} \mathrm{min).} \mathrm{Meantime,} \mathrm{an} \mathrm{IR}$ camera was deployed to record thermal images. Body weights and wound sizes were recorded every 2 days post wounding until all mice were sacrificed on the 8th day after treatment. Meanwhile, in vivo biosafety and wound healing was investigated through HE staining, masson's trichrome staining, and immunofluorescence staining (CD31, VEGF), utilizing skin tissues and main organs (liver, spleen, lung, and kidney) harvested. For the Western blot analyses, formalin-fixed, paraffin-embedded (FFPE) skin wound samples were sectioned at a thickness of $10 \mu \mathrm{m}$. After sections were dewaxed by adding $500 \mu \mathrm{L}$ of octane and vigorously shaken for $10 \mathrm{~s}, 750 \mu \mathrm{L}$ methanol was added and shaken for another $10 \mathrm{~s}$. Samples were then centrifuged $\left(15,000 \mathrm{~g}, 10 \mathrm{~min}, 4^{\circ} \mathrm{C}\right)$ to remove the upper suspension, and pellets were dried for $5 \mathrm{~min} .50 \mu \mathrm{l}$ of lysis buffer containing $20 \mathrm{mM}$ Tris-HCl (pH 7.4) and 2\% SDS was added, followed by heating at $100{ }^{\circ} \mathrm{C}$ for $20 \mathrm{~min}$ and $60^{\circ} \mathrm{C}$ for $2 \mathrm{~h}$. Samples were then collected and went through western blot assay. Expression variation of CD31 and HIF-1a was tested. 


\section{Declarations}

Acknowledgments

We thank We thank the Instrumental Analysis Center of Shanghai Jiao Tong University for materials testing.

Author's contributions

$\mathrm{YH}, \mathrm{JF}$ and $\mathrm{YY}$ designed the plan of the experiments. YY and JF performed the synthesis and characterization experiments of the material. $\mathrm{YY}$ and $\mathrm{CW}$ performed the in vitro experiments. $\mathrm{YY}$, JF, and $\mathrm{JL}$ participated in the in vivo experiments. NW, JL, YZ and JZ contributed to data analysis. YY and JF drafted the manuscript. YY, JF and YH contributed to the manuscript preparation. All authors read and approved the final manuscript.

\section{Funding}

We acknowledge the financial support from the National Natural Science Foundation of China (Nos. 81801821, 81972058, and 51872313), and Shanghai Municipal Key Clinical Specialty (No. shslczdzk06701).

Availability of data and materials

All data generated or analyzed during this study are included in this article.

Consent for publication

All authors agree to be published.

Competing interests

The authors declare that they have no competing interests.

Author details

${ }^{1}$ Shanghai Key Laboratory of Orthopaedic Implant, Department of Orthopaedic Surgery, Shanghai Ninth People's Hospital, Shanghai Jiao Tong University School of Medicine, Shanghai 200011, China. ${ }^{2}$ Clinical and Translational Research Center for 3D Printing Technology, Shanghai Ninth People's Hospital, Shanghai Jiao Tong University School of Medicine, Shanghai 200011, China. ${ }^{3}$ Department of Orthopedics, The Second Affiliated Hospital of Harbin Medical University, Harbin 150081, China. 4 Shanghai Electrochemical Energy Devices Research Center, School of Chemistry and Chemical Engineering and State Key Laboratory of Metal Matrix Composites, Shanghai Jiao Tong University, Shanghai 200240, China. ${ }^{5}$ Key Laboratory of Inorganic Coating Materials, Shanghai Institute of Ceramics, Chinese Academy of Sciences, Shanghai 200050, China. 


\section{References}

1. Levy SB, Marshall B. Antibacterial resistance worldwide: causes, challenges and responses. Nat Med. 2004;10:122-9.

2. Wang CY, Makvandi P, Zare EN, Tay FR, Niu LN. Advances in antimicrobial organic and inorganic nanocompounds in biomedicine. Adv Therap. 2020;3:2000024.

3. Jiao Y, Niu LN, Ma S, Li J, Tay FR, Chen JH. Quaternary ammonium-based biomedical materials: State-of-the-art, toxicological aspects and antimicrobial resistance. Prog Polym Sci. 2017;71:53-90.

4. Ding XK, Duan S, Ding XJ, Liu RH, Xu FJ. Versatile antibacterial materials: An emerging arsenal for combatting bacterial pathogens. Adv Funct Mater. 2018;28:1802140.

5. Li X, Bai HT, Yang YC, Yoon J, Wang S, Zhang X. Supramolecular antibacterial materials for combatting antibiotic resistance. Adv Mater. 2019;31:1805092.

6. Hu XL, Shang Y, Yan KC, Sedgwick AC, Gan HQ, Chen GR, He XP, James TD, Chen DJ. Lowdimensional nanomaterials for antibacterial applications. J Mater Chem B. 2021;9:3640-61.

7. You JH, Guo YZ, Guo R, Liu XW. A review of visible light-active photocatalysts for water disinfection: Features and prospects. Chem Eng J. 2019;373:624-41.

8. Zhou ZL, Li B, Liu XM, Li ZY, Zhu SL, Liang YQ, Cui ZD, Wu SL. Recent progress in photocatalytic antibacterial. ACS Appl Bio Mater. 2021;4:3909-36.

9. Wang WJ, Li GY, Xia DH, An TC, Zhao HJ, Wong PK. Photocatalytic nanomaterials for solar-driven bacterial inactivation: recent progress and challenges. Environ Sci-Nano. 2017;4:782-99.

10. Li Y, Liu XM, Tan L, Cui ZD, Yang XJ, Zheng YF, Yeung KWK, Chu PK, Wu SL. Rapid sterilization and accelerated wound healing using $\mathrm{Zn}^{2+}$ and graphene oxide modified $\mathrm{g}-\mathrm{C}_{3} \mathrm{~N}_{4}$ under dual light irradiation. Adv Funct Mater. 2018;28:1800299.

11. Zhang Y, Sun PP, Zhang L, Wang ZZ, Wang FM, Dong K, Liu Z, Ren JS, Qu XG. Silver-infused porphyrinic metal-organic framework: Surface-adaptive, on-demand nanoplatform for synergistic bacteria killing and wound disinfection. Adv Funct Mater. 2019;29:1808594.

12. Lambeth JD. Nox enzymes and the biology of reactive oxygen. Nat Rev Immunol. 2004;4:181-9.

13. Ren YW, Liu HP, Liu XM, Zheng YF, Li ZY, Li CY, Yeung KWK, Zhu SL, Liang YQ, Cui ZD, Wu SL. Photoresponsive materials for antibacterial applications. Cell Rep Phys Sci. 2020;1:100245.

14. Yang R, Song G, Wang L, Yang Z, Zhang J, Zhang X, Wang S, Ding L, Ren N, Wang A, Yu X. Full solarspectrum-driven antibacterial therapy over hierarchical $\mathrm{Sn}_{3} \mathrm{O}_{4} / \mathrm{PDINH}$ with enhanced photocatalytic activity. Small. 2021;17:2102744.

15. Makabenta JMV, Nabawy A, Li CH, Schmidt-Malan S, Patel R, Rotello VM. Nanomaterial-based therapeutics for antibiotic-resistant bacterial infections. Nat Rev Microbiol. 2021;19:23-36.

16. Reddy VRM, Pallavolu MR, Guddeti PR, Gedi S, Reddy KKYB, Pejjai B, Kim WK, Kotte TRR, Park C. Review on $\mathrm{Cu}_{2} \mathrm{SnS}_{3}, \mathrm{Cu}_{3} \mathrm{SnS}_{4}$, and $\mathrm{Cu}_{4} \mathrm{SnS}_{4}$ thin films and their photovoltaic performance. $\mathrm{J}$ Ind Eng Chem. 2019;76:39-74. 
17. Munoz-Batista MJ, Fontelles-Carceller O, Ferrer M, Fernandez-Garcia M, Kubacka A. Disinfection capability of $\mathrm{Ag} / \mathrm{g}-\mathrm{C}_{3} \mathrm{~N}_{4}$ composite photocatalysts under UV and visible light illumination. Appl Catal B-Environ. 2016;183:86-95.

18. Han QY, Lau JW, Do HC, Zhang ZJ, Xing BG. Near-infrared light brightens bacterial disinfection: Recent progress and perspectives. ACS Appl Bio Mater. 2021;4:3937-61.

19. Wang X, Shi Q, Zha Z, Zhu D, Zheng L, Shi L, Wei X, Lian L, Wu K, Cheng L. Copper single-atom catalysts with photothermal performance and enhanced nanozyme activity for bacteria-infected wound therapy. Bioact Mater. 2021;6:4389-401.

20. Tang H, Qu X, Zhang W, Chen X, Zhang S, Xu Y, Yang H, Wang Y, Yang J, Yuan WE, Yue B. Photosensitizer nanodot eliciting immunogenicity for photo-immunologic therapy of postoperative methicillin-resistant staphylococcus aureus infection and secondary recurrence, Adv. Mater. https://doi.org/10.1002/adma.202107300.

21. Borkow G. Using copper to improve the well-being of the skin. Curr Chem Biol. 2014;8:89-102.

22. Lokhande AC, Shelke A, Babar PT, Kim J, Lee DJ, Kim IC, Lokhandee CD, Kim JH. Novel antibacterial application of photovoltaic $\mathrm{Cu}_{2} \mathrm{SnS}_{3}$ (CTS) nanoparticles. RSC Adv. 2017;7:33737-44.

23. Ali N, Tsega TT, Cao YC, Abbas S, Li WJ, Iqbal A, Fazal H, Xin ZL, Zai JT, Qian XF. Copper vacancy activated plasmonic $\mathrm{Cu}_{3}-\mathrm{xSnS}$ for highly efficient photocatalytic hydrogen generation: Broad solar absorption, efficient charge separation and decreased HER overpotential. Nano Res. 2021;14:335864.

24. Chen FK, Zai JT, Xu M, Qian XF. 3D-hierarchical $\mathrm{Cu}_{3} \mathrm{SnS}_{4}$ flowerlike microspheres: Controlled synthesis, formation mechanism and photocatalytic activity for $\mathrm{H}_{2}$ evolution from water. J Mater Chem A. 2013;1:4316-23.

25. Hu HM, Liu ZP, Yang BJ, Chen XY, Qian YT. Template-mediated growth of $\mathrm{Cu}_{3} \mathrm{SnS}_{4}$ nanoshell tubes. J Cryst Growth. 2005;284:226-34.

26. Xiong YJ, Xie Y, Du GA, Su HL. From 2D framework to quasi-1D nanomaterial: Preparation, characterization, and formation mechanism of $\mathrm{Cu}_{3} \mathrm{SnS}_{4}$ nanorods. Inorg Chem. 2002;41:2953-9.

27. Fu LH, Wan YL, Qi C, He J, Li CY, Yang C, Xu H, Lin J, Huang P. Nanocatalytic theranostics with glutathione depletion and enhanced reactive oxygen species generation for efficient cancer therapy. Adv Mater. 2021;33:2006892.

28. Zhou XR, Zhu Y, Niu QY, Zeng GM, Lai C, Liu SY, Huang DL, Qin L, Liu XG, Li BS, Yi H, Fu YK, Li L, Zhang MM, Zhou CY, Liu JH. New notion of biochar: A review on the mechanism of biochar applications in advannced oxidation processes. Chem Eng J. 2021;416:129027.

29. Zhou L, Song W, Chen ZQ, Yin GC. Degradation of organic pollutants in wastewater by bicarbonateactivated hydrogen peroxide with a supported cobalt catalyst. Environ Sci Technol. 2013;47:3833-9.

30. Ge L, Chen JW, Lin J, Cai XY. Light-Source-dependent effects of main water constituents on photodegradation of phenicol antibiotics: Mechanism and kinetics. Environ Sci Technol. 2009;43:3101-7. 
31. Khan A, Zhang KK, Taraqqi-A-Kamal A, Wang XG, Chen Y, Zhang YR. Degradation of antibiotics in aqueous media using manganese nanocatalyst-activated peroxymonosulfate. J Colloid Interf Sci. 2021;599:805-18.

32. Yin MC, Li ZS, Kou JH, Zou ZG. Mechanism investigation of visible light-induced degradation in a heterogeneous $\mathrm{TiO}_{2}$ /Eosin Y/Rhodamine B system. Environ Sci Technol. 2009;43:8361-6.

33. Wang LW, Zhang X, Yu X, Gao EN, Shen ZY, Zhang XL, Ge SG, Liu J, Gu ZJ, Chen CY. An all-organic semiconductor $\mathrm{C}_{3} \mathrm{~N}_{4}$ /PDINH heterostructure with advanced antibacterial photocatalytic therapy activity. Adv Mater. 2019;31:1901965.

34. Li YW, Ling WD, Han QF, Kim TW, Shi WZ. Localized surface plasmon resonances and its related defects in orthorhombic $\mathrm{Cu}_{3} \mathrm{SnS}_{4}$ nanocrystals. J Alloy Compd. 2015;633:347-52.

35. Zhang X, Zhang G, Chai M, Yao X, Chen W, Chu PK. Synergistic antibacterial activity of physicalchemical multi-mechanism by $\mathrm{TiO}_{2}$ nanorod arrays for safe biofilm eradication on implant. Bioact Mater. 2021;6:12-25.

36. Guillamat-Prats R. The role of MSC in wound healing, scarring and regeneration. Cells. 2021;10:1729.

37. Dong CH, Feng W, Xu WW, Yu LD, Xiang H, Chen Y, Zhou JQ. The coppery age: Copper (Cu)-involved nanotheranostics. Adv Sci. 2020;7:2001549.

38. Xiao JS, Chen SY, Yi J, Zhang HF, Ameer GA. A cooperative copper metal-organic framework-hydrogel system improves wound healing in diabetes. Adv Funct Mater. 2017;27:1604872.

39. Rucker RB, Kosonen T, Clegg MS, Mitchell AE, Rucker BR, Uriu-Hare JY, Keen CL. Copper, lysyl oxidase, and extracellular matrix protein cross-linking. Am J Clin Nutr. 1998;67:996s-1002s.

40. Li Y, Fu R, Duan Z, Zhu C, Fan D. Construction of multifunctional hydrogel based on the tannic acidmetal coating decorated $\mathrm{MoS}_{2}$ dual nanozyme for bacteria-infected wound healing. Bioact Mater. 2022;9:461-74.

41. Valarmathi MT, Davis JM, Yost MJ, Goodwin RL, Potts JD. A three-dimensional model of vasculogenesis. Biomaterials. 2009;30:1098-112.

42. Fan W, Crawford $R$, Xiao Y. Enhancing in vivo vascularized bone formation by cobalt chloride-treated bone marrow stromal cells in a tissue engineered periosteum model. Biomaterials. 2010;31:3580-9.

43. Ahluwalia A, Tarnawski AS. Critical role of hypoxia sensor - HIF-1a in VEGF gene activation. Implications for angiogenesis and tissue injury healing. Curr Med Chem. 2012;19:90-7.

44. Heun Y, Pogoda K, Anton M, Pircher J, Pfeifer A, Woernle M, Ribeiro A, Kameritsch P, Mykhaylyk O, Plank C, Kroetz F, Pohl U, Mannell H. HIF-1a dependent wound healing angiogenesis in vivo can be controlled by site-specific lentiviral magnetic targeting of SHP-2. Mol Ther. 2017;25:1616-27.

45. Perez-Jimenez Al, Lyu D, Lu ZX, Liu GK, Ren RB. Surface-enhanced Raman spectroscopy: benefits, trade-offs and future developments. Chem Sci. 2020;11:4563-77.

46. Zhou X, Hu ZW, Yang DT, Xie SX, Jiang ZJ, Niessner R, Haisch C, Zhou HB, Sun PH. Bacteria detection: From powerful SERS to its advanced compatible techniques. Adv Sci. 2020;7:2001739. 
47. Xu J, Liu N, Wu D, Gao Z, Song YY, Schmuki P. Upconversion nanoparticle-assisted payload delivery from $\mathrm{TiO}_{2}$ under near-infrared light irradiation for bacterial inactivation. ACS Nano. 2020;14:337-46.

48. Qiu Y, Lin M, Chen G, Fan C, Li M, Gu X, Cong S, Zhao Z, Fu L, Fang X, Xiao Z. Photodegradable CuS SERS probes for intraoperative residual tumor detection, ablation, and self-clearance. ACS Appl Mater Inter. 2019;11:23436-44.

49. He J, Qiao Y, Zhang H, Zhao J, Li W, Xie T, Zhong D, Wei Q, Hua S, Yu Y, Yao K, Santos HA, Zhou M. Gold-silver nanoshells promote wound healing from drug-resistant bacteria infection and enable monitoring via surface-enhanced Raman scattering imaging. Biomaterials. 2020;234:119763.

50. Hsu YK, Chen ZB, Lin YC, Chen YC, Chen SY, Lin YG. Room-temperature fabrication of $\mathrm{Cu}$ nanobrushes as an effective surface-enhanced Raman scattering substrate. Crystengcomm. 2016;18:8284-90.

\section{Figures}
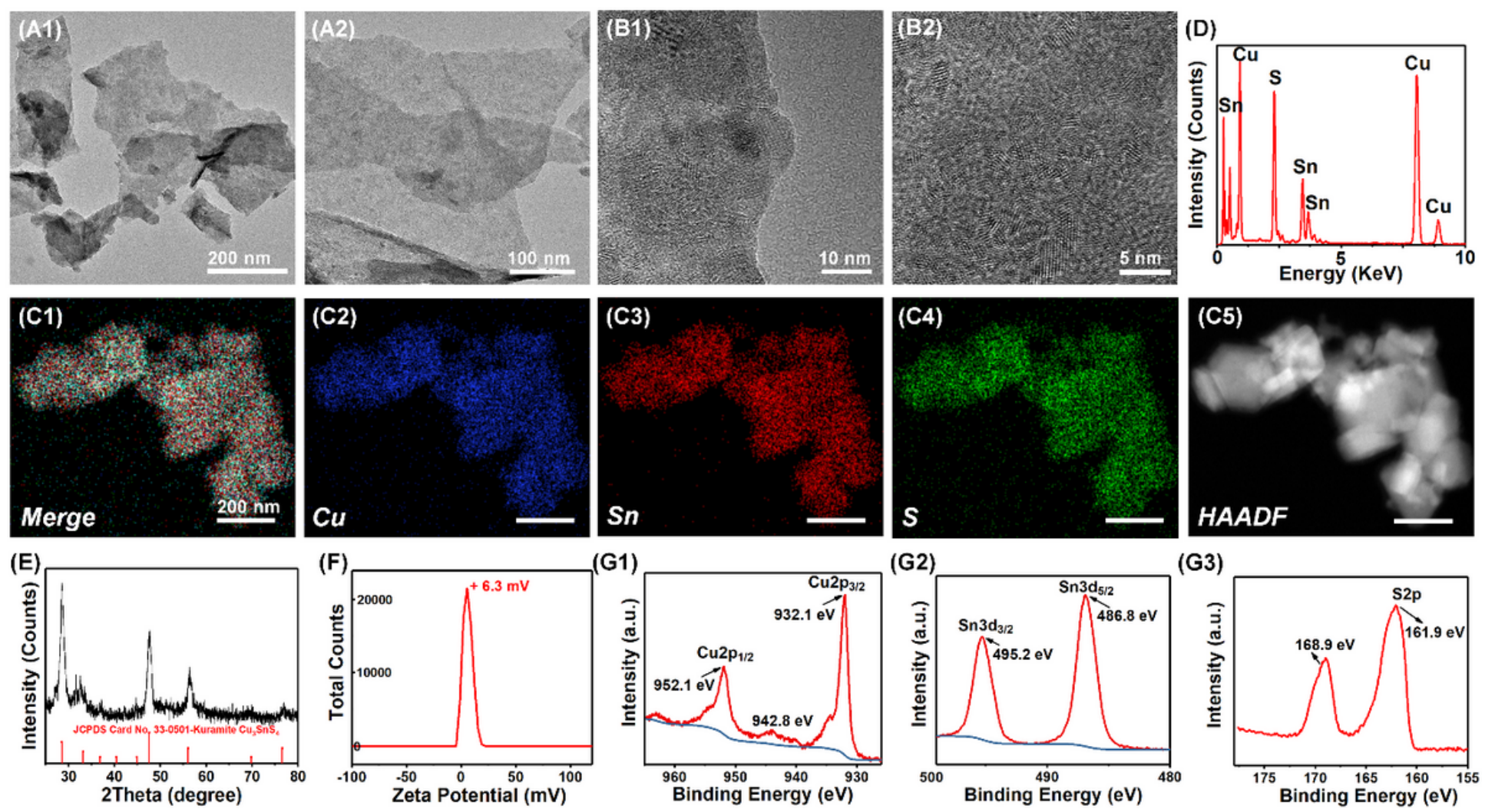

\section{Figure 1}

Characterization of as-prepared $\mathrm{Cu}_{3} \mathrm{SnS}_{4} \mathrm{NFs}$. (A, B) TEM images of $\mathrm{Cu}_{3} \mathrm{SnS}_{4} \mathrm{NFs}$. (C) Element mappings of $\mathrm{Cu}, \mathrm{Sn}$ and $\mathrm{S}$ elements in $\mathrm{Cu}_{3} \mathrm{SnS}_{4}$. (D) EDS of the $\mathrm{Cu}_{3} \mathrm{SnS}_{4} \mathrm{NFs}$. (E) XRD pattern of the as-prepared $\mathrm{Cu}_{3} \mathrm{SnS}_{4}$ and the standard JCPDS card No. 33-0501. (F) Zeta potential of the $\mathrm{Cu}_{3} \mathrm{SnS}_{4}$. (G) XPS analyses of the $\mathrm{Cu}_{3} \mathrm{SnS}_{4}$. 


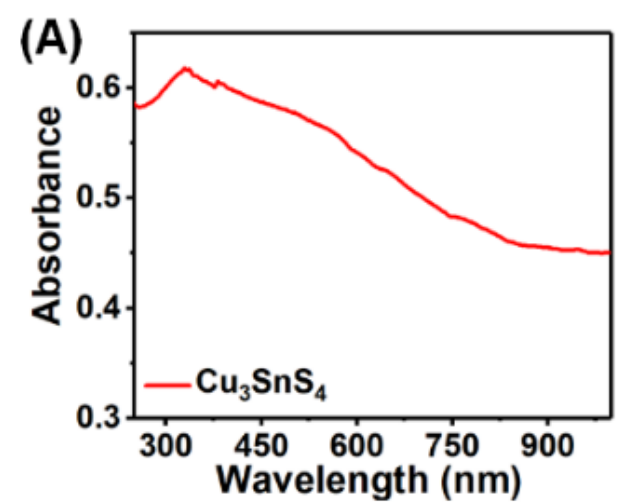

(D)

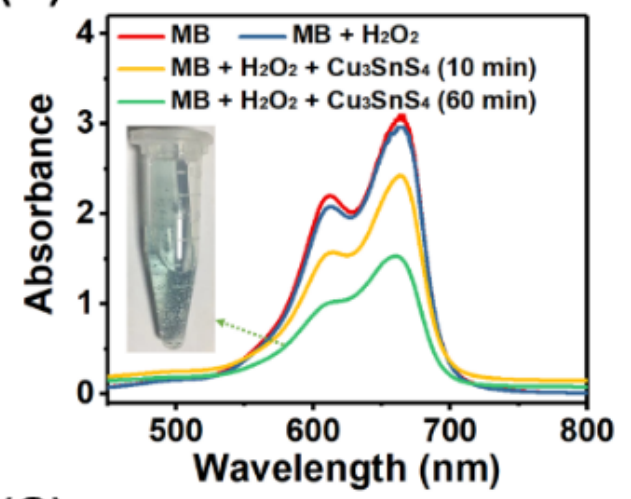

(G)

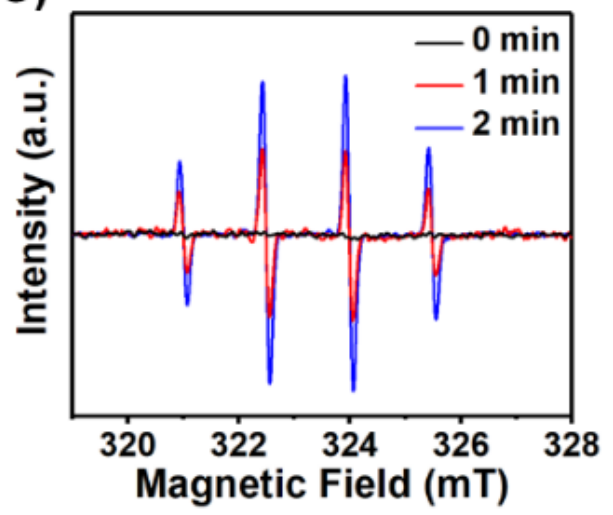

(B)

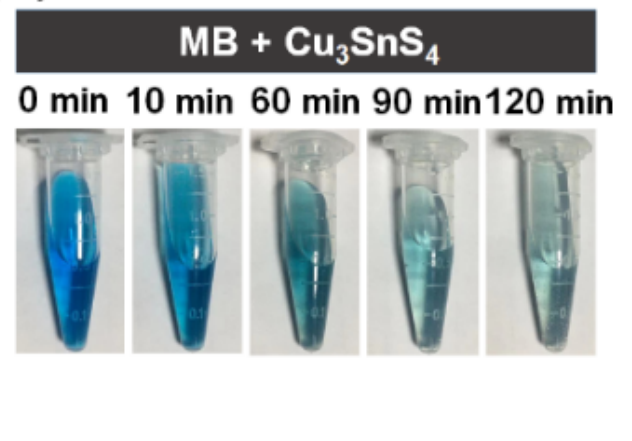

(E)

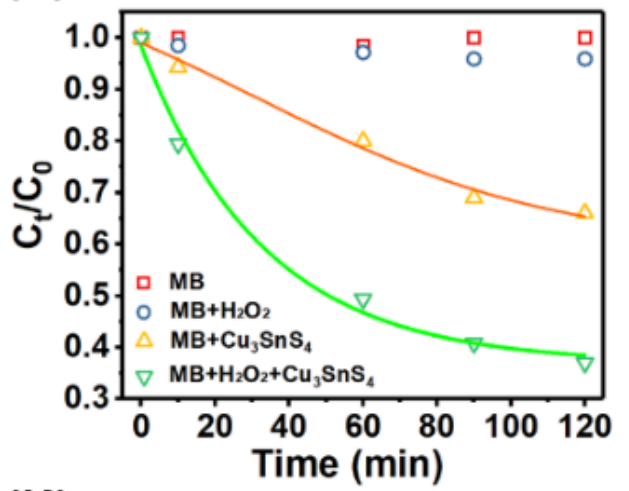

(H)

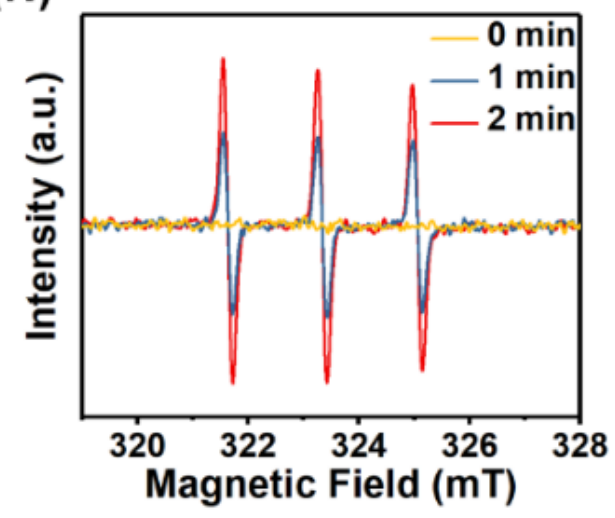

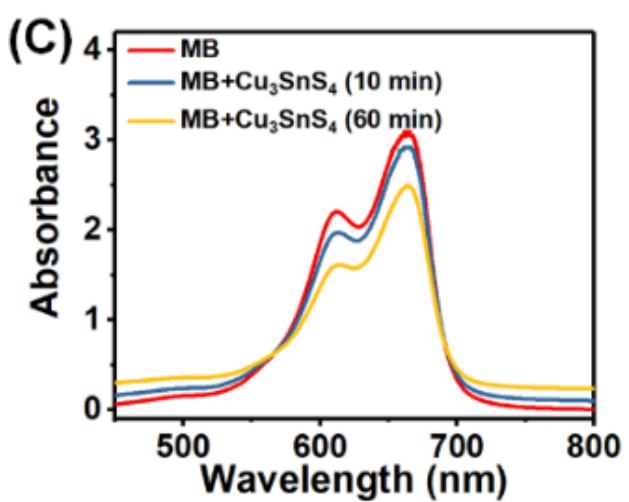

( $F)$

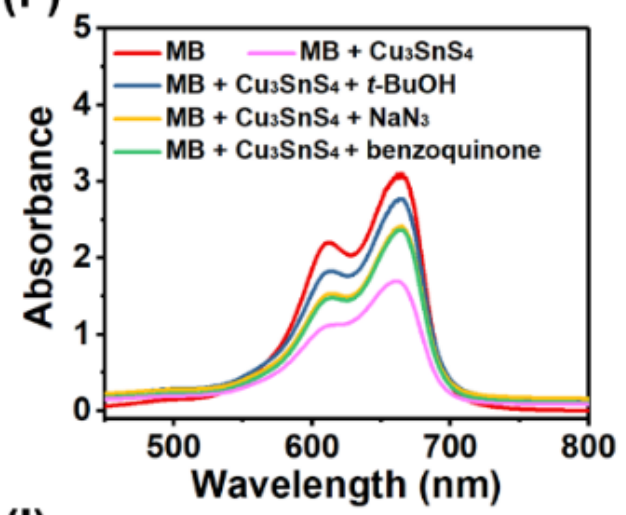

(I)

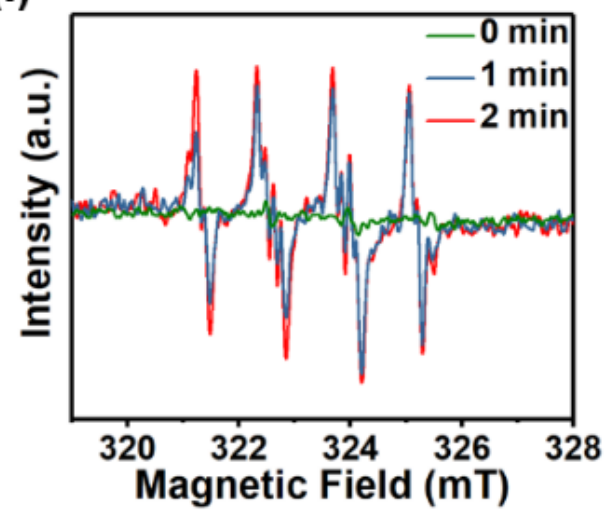

Figure 2

(A) The UV/Vis/NIR absorption spectrum of the $\mathrm{Cu}_{3} \mathrm{SnS}_{4}$ NFs. (B) Photographs of the $\mathrm{Cu}_{3} \mathrm{SnS}_{4}$ mediated and time-dependent degradation of MB. (C) Time-dependent UV/Vis absorption spectra of MB solution after incubation with $\mathrm{Cu}_{3} \mathrm{SnS}_{4}$ under visible light irradiation. (D) Time-dependent UV/Vis absorption spectra of $\mathrm{MB}$ solution after incubation with $\mathrm{Cu}_{3} \mathrm{SnS}_{4}$ and/or $\mathrm{H}_{2} \mathrm{O}_{2}$ under visible light irradiation. (E) Time-dependent concentration change of $\mathrm{MB}$ after incubation with $\mathrm{Cu}_{3} \mathrm{SnS}_{4}$ and/or $\mathrm{H}_{2} \mathrm{O}_{2}$. $(\mathrm{F}) \mathrm{UV} / \mathrm{Vis}$ absorption spectra of $\mathrm{MB}$ solution after incubation with $\mathrm{Cu}_{3} \mathrm{SnS}_{4}$ in the presence of $t-\mathrm{BuOH}, \mathrm{NaN}_{3}$, or benzoquinone, demonstrating the influence of $t \mathrm{BuOH}, \mathrm{NaN}_{3}$, and benzoquinone on the $\mathrm{Cu}_{3} \mathrm{SnS}_{4}{ }^{-}$ activated MB degradation. (G-I) EPR spectra of $\mathrm{G}) \cdot \mathrm{OH}, \mathrm{H}){ }^{1} \mathrm{O}_{2}$, and I) $\mathrm{O}_{2} \cdot-$ upon dispersion of $\mathrm{Cu}_{3} \mathrm{SnS}_{4}$ into deionized water under visible light irradiation for different times. 
(A) $0 \min 2 \min 4 \min 6 \min 8 \min 10 \min$

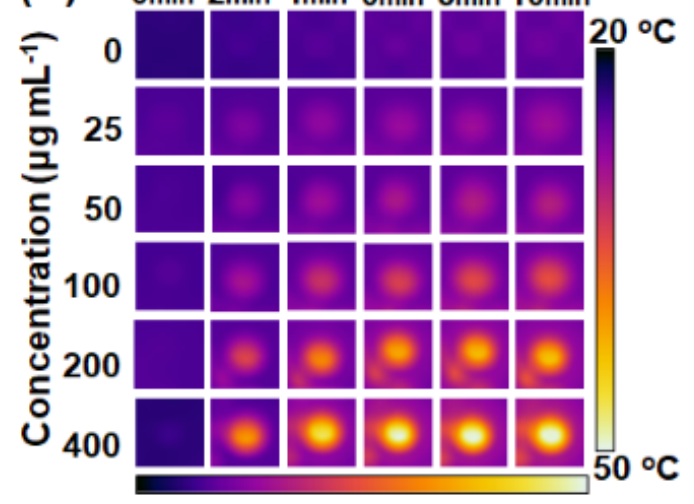

(D) 5

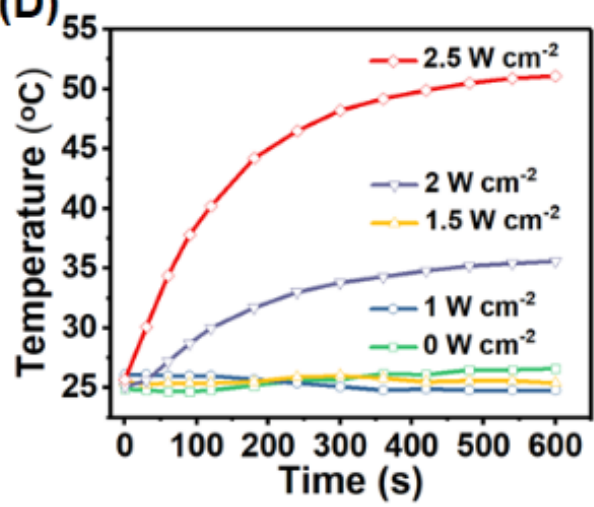

(G)

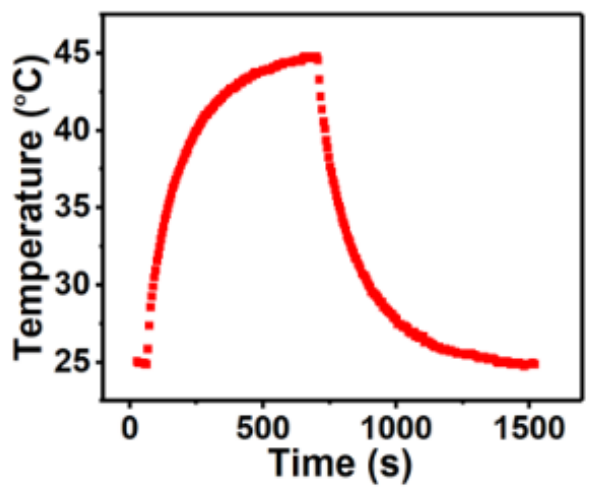

(B)

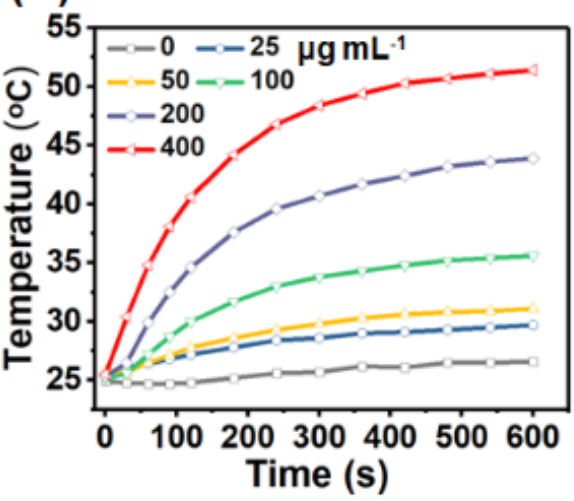

(E)

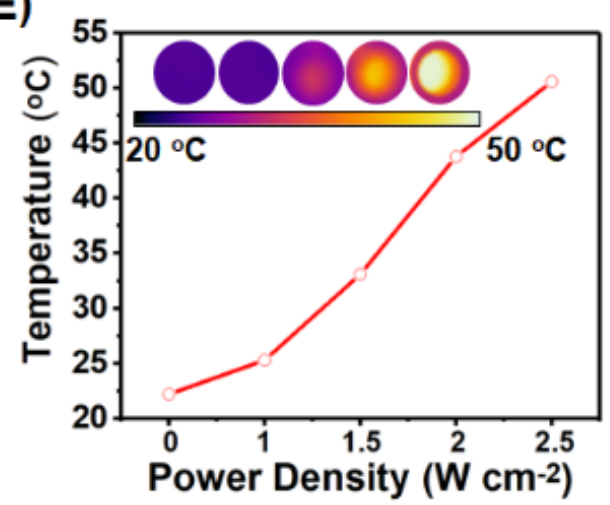

(H)

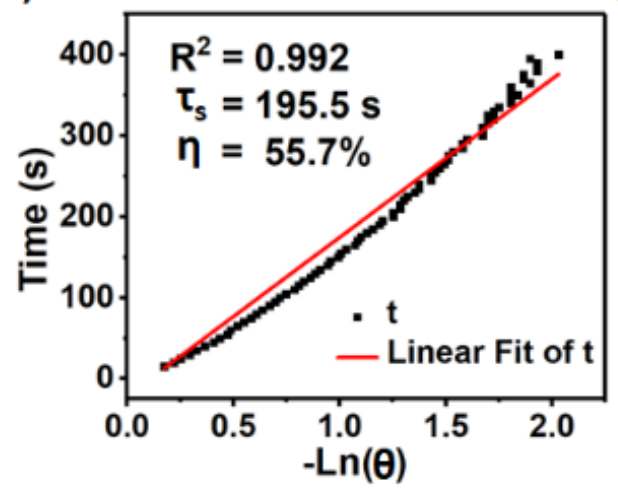

(C)

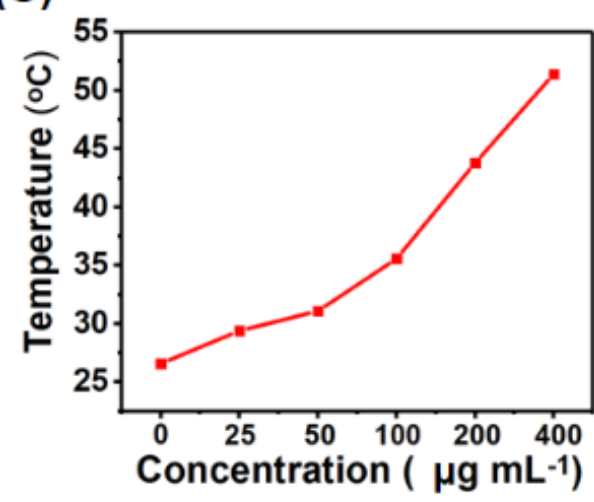

(F)

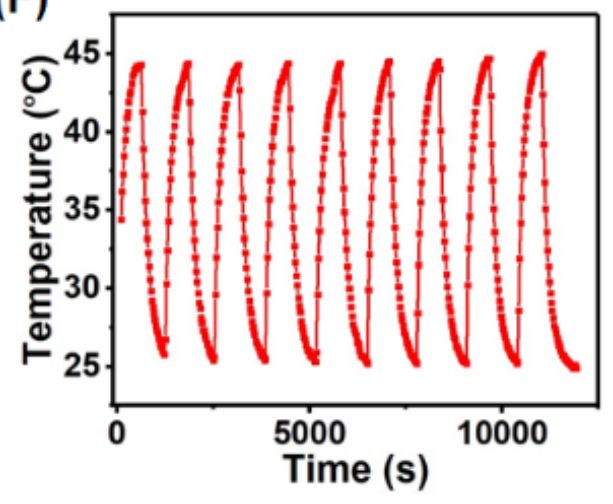

(I)

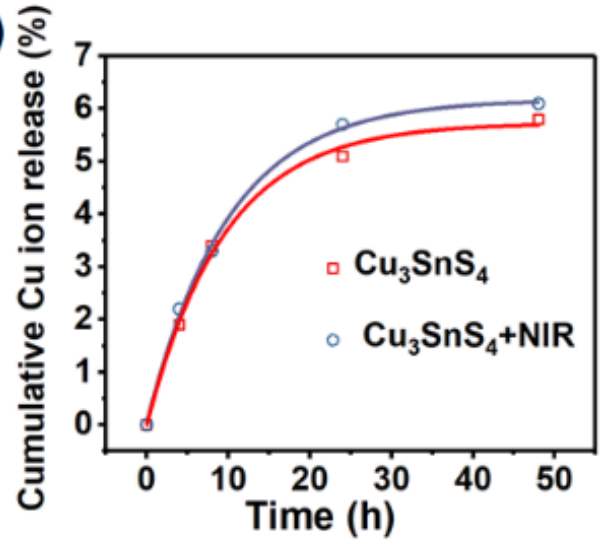

Figure 3

(A-C) Infrared thermal images and corresponding photothermal heating curves of pure water and aqueous dispersions of $\mathrm{Cu}_{3} \mathrm{SnS}_{4}$ at different $\mathrm{Cu}_{3} \mathrm{SnS}_{4}$ concentrations under continuous irradiation by a $808 \mathrm{~nm}$ laser with a power density of $2.5 \mathrm{~W} \mathrm{~cm}^{-2}$. (D, E) Photothermal heating curves of aqueous dispersions of $\mathrm{Cu}_{3} \mathrm{SnS}_{4}$ by a $808 \mathrm{~nm}$ laser with varied power density. $(\mathrm{F})$ Temperature changes of $\mathrm{Cu}_{3} \mathrm{SnS}_{4}$ aqueous dispersions over nine cycles of irradiation/cooling processes. (G) The temperature profile of $\mathrm{Cu}_{3} \mathrm{SnS}_{4}$ aqueous dispersions irradiated with a 808-nm laser, followed by natural cooling after the laser was turned off. $(\mathrm{H})$ Determination of the system time constant using linear regression of the 
cooling profile shown in (G). (I) Cu ions release from the $\mathrm{Cu}_{3} \mathrm{SnS}_{4}$ in PBS (pH 7.4) in the presence or absence of the NIR irradiation.

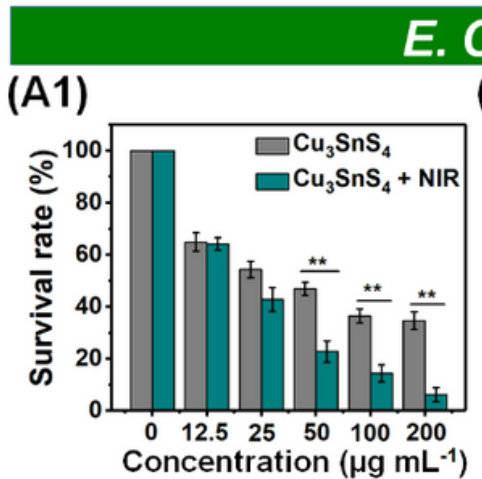

(C1)

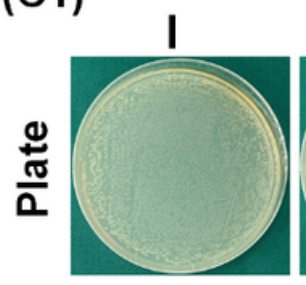

(D)
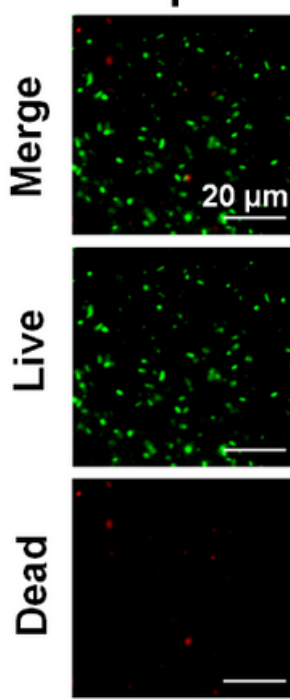

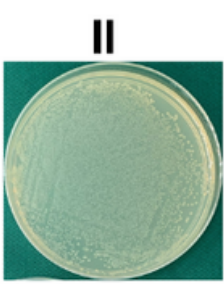

II
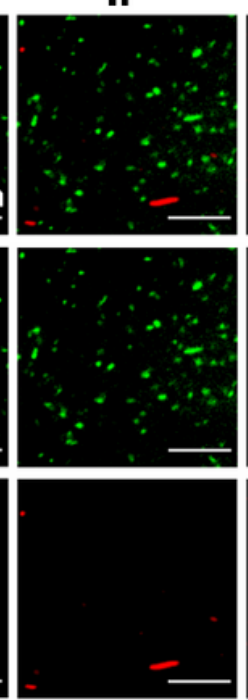

(B1)
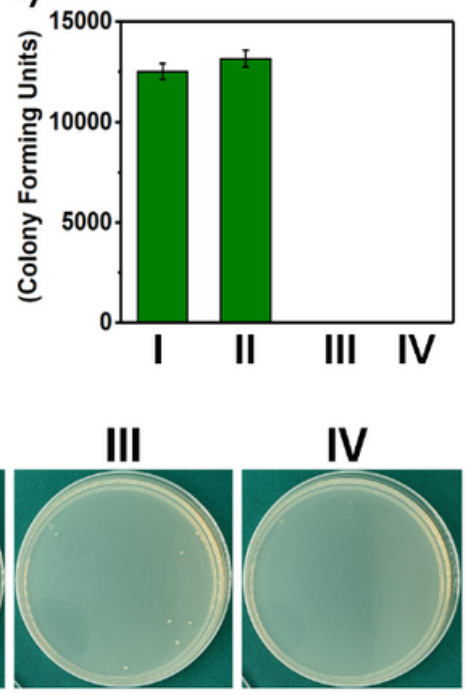

III
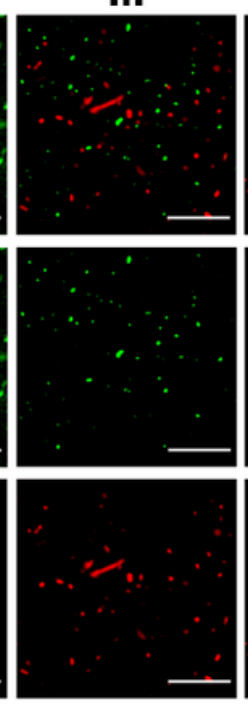

IV
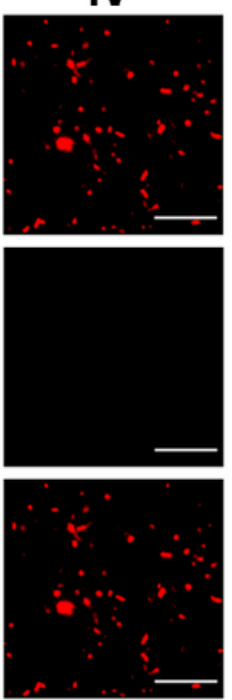

\section{MRSA}

(B2)
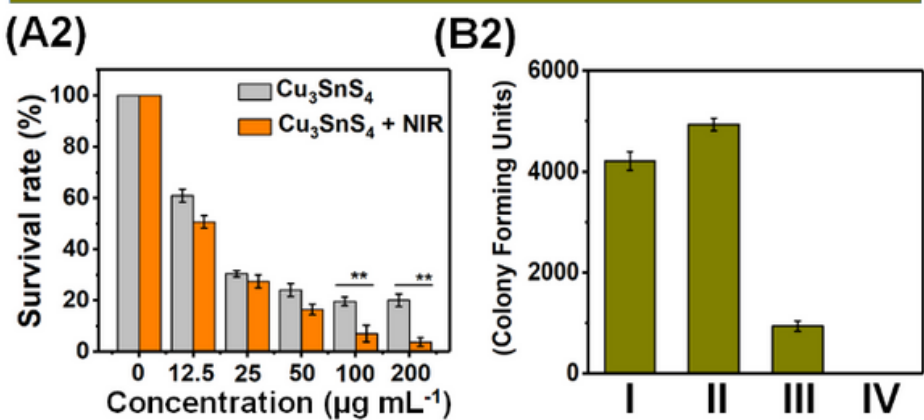

(C2)
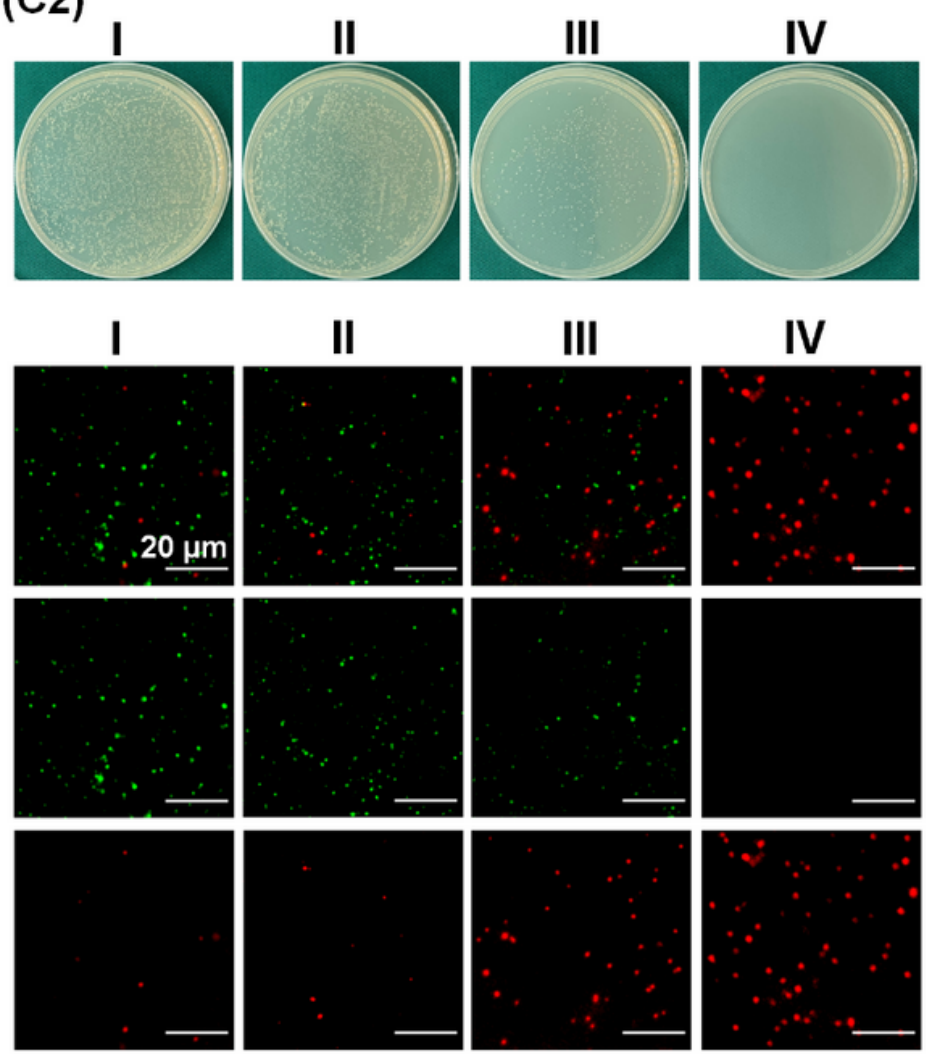

Figure 4

(A) Growth survival of (A1) E. coli and (A2) MRSA bacteria. Data are presented as means \pm SDs $(n=6) .{ }^{*} p$ $<0.05,{ }^{* *} p<0.01$. (B) CFU amount of (B1) E. coli and (B2) MRSA bacteria. (C) Photographs of (C1) E. coli and (C2) MRSA bacterial colonies formed on lysogeny broth (LB)-agar plates. (D) Representative CLSM images of live/dead staining assay for $E$. coli (left) and MRSA (right) after different treatments via SYTO9 (green, viable bacteria) and PI (red, dead bacteria) staining. Group I: control group in the absence of NFs and NIR irradiation; Group II: NIR group with the irradiation of NIR laser ( $\left.808 \mathrm{~nm}, 1.5 \mathrm{~W} \mathrm{~cm}^{-2}, 10 \mathrm{~min}\right)$ in the absence of NFs; Group III: $\mathrm{Cu}_{3} \mathrm{SnS}_{4}$ group with the treatment with $\mathrm{Cu}_{3} \mathrm{SnS}_{4} \mathrm{NFs}$ under no laser 
irradiation; Group IV: $\mathrm{Cu}_{3} \mathrm{SnS}_{4}+$ NIR group with the treatment with $\mathrm{Cu}_{3} \mathrm{SnS}_{4}$ NFs plus NIR irradiation (808 $\left.\mathrm{nm}, 1.5 \mathrm{~W} \mathrm{~cm}^{-2}, 10 \mathrm{~min}\right)$. All groups were exposed to visible light for $20 \mathrm{~min}$.
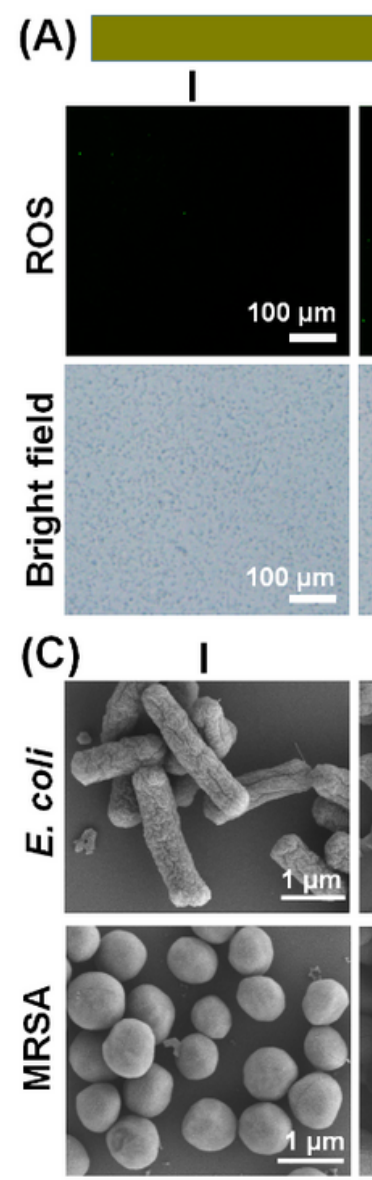
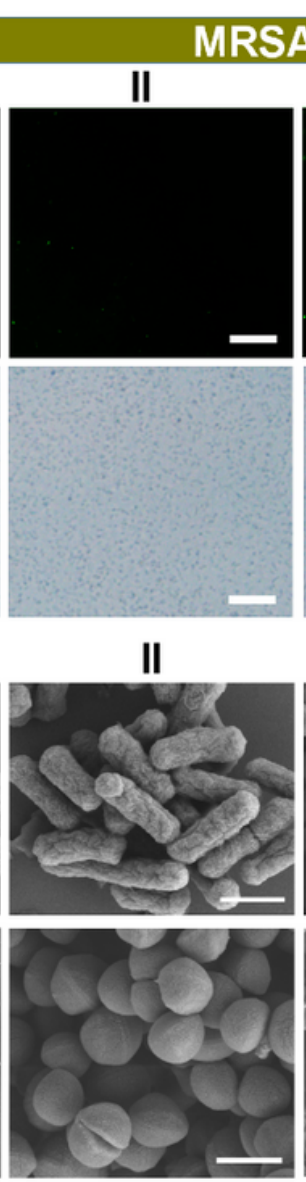

III

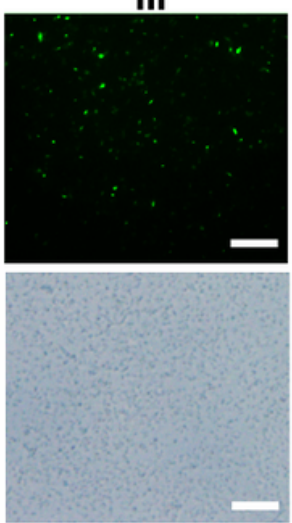

III

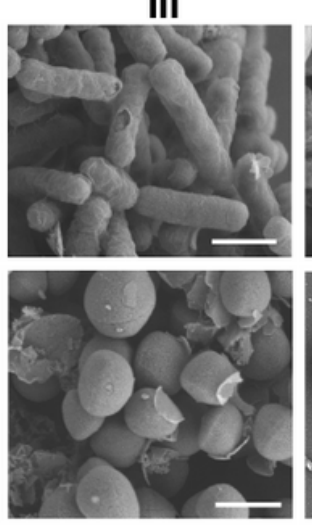

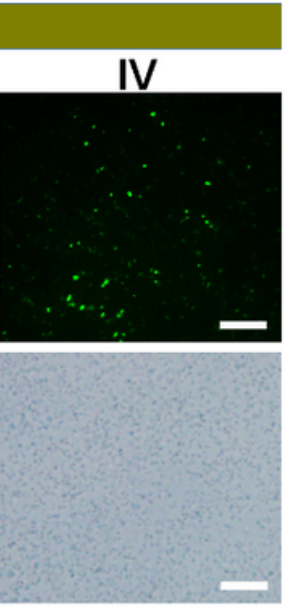

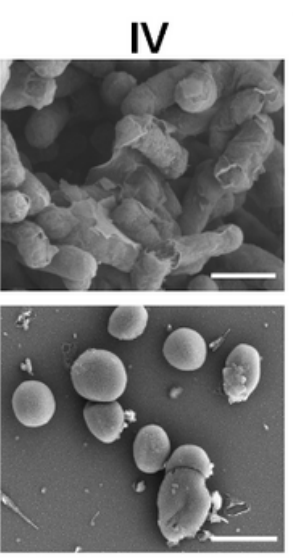

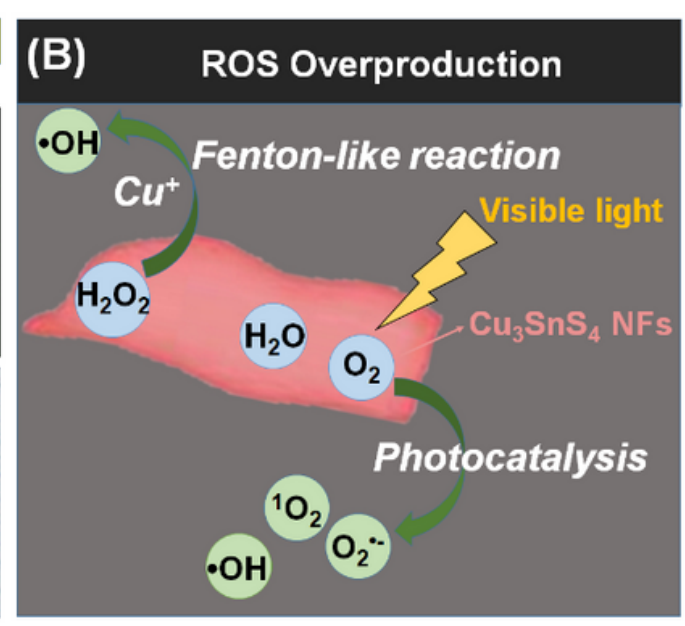

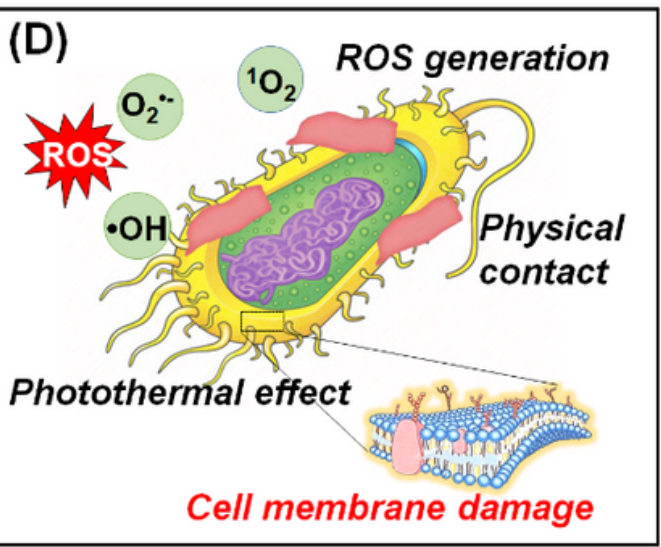

Figure 5

(A) Intracellular ROS level indicated by DCFH-DA fluorescence staining and the corresponding bright-field micrographs after diverse treatments. (B) Scheme of the ROS overproduction induced by the Cu ions mediated Fenton-like reaction and the visible light mediated photocatalytic process. (C) SEM micrographs of $E$. coli and MRSA after different treatments. (D) Scheme of the interaction of the physical contact, ROS generation and photothermal effects, which collaboratively led to the damage of bacteria cell membrane. Group I: control group in the absence of NFs; Group II: NIR group with the irradiation of NIR laser (808 nm, $1.5 \mathrm{~W} \mathrm{~cm}^{-2}, 10 \mathrm{~min}$ ) in the absence of NFs; Group III: $\mathrm{Cu}_{3} \mathrm{SnS}_{4}$ group with the treatment with $\mathrm{Cu}_{3} \mathrm{SnS}_{4} \mathrm{NFs}$ under no laser irradiation; Group IV: $\mathrm{Cu}_{3} \mathrm{SnS}_{4}+\mathrm{NIR}$ group with the treatment with $\mathrm{Cu}_{3} \mathrm{SnS}_{4}$ NFs plus NIR irradiation (808 nm, $1.5 \mathrm{~W} \mathrm{~cm}^{-2}, 10 \mathrm{~min}$ ). All groups were exposed to visible light for $20 \mathrm{~min}$. 

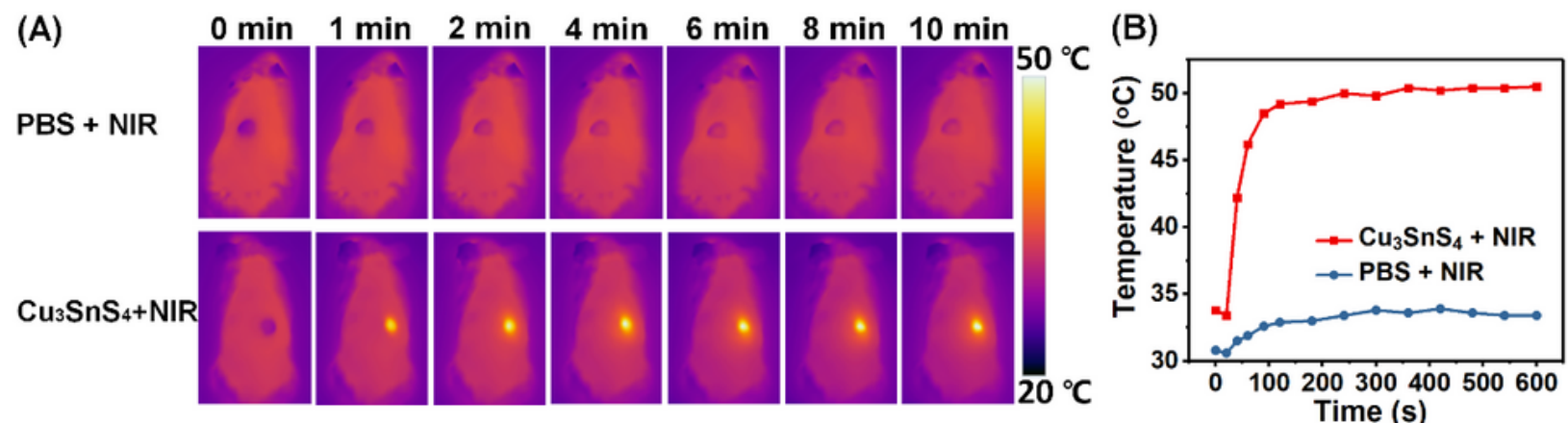

(C)

Visible light mediated anti-bacteria

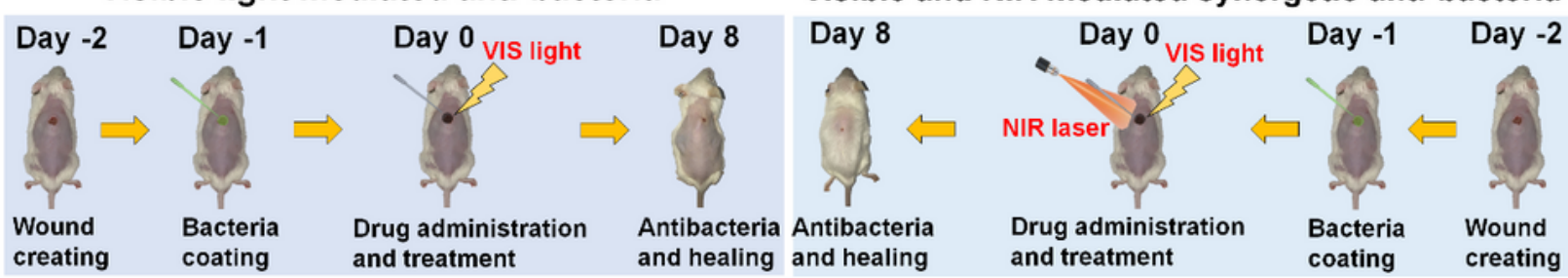

(D)

Control

$\begin{array}{lllll}\text { Day } 0 & \text { Day } 2 & \text { Day } 4 & \text { Day } 6 & \text { Day } 8\end{array}$

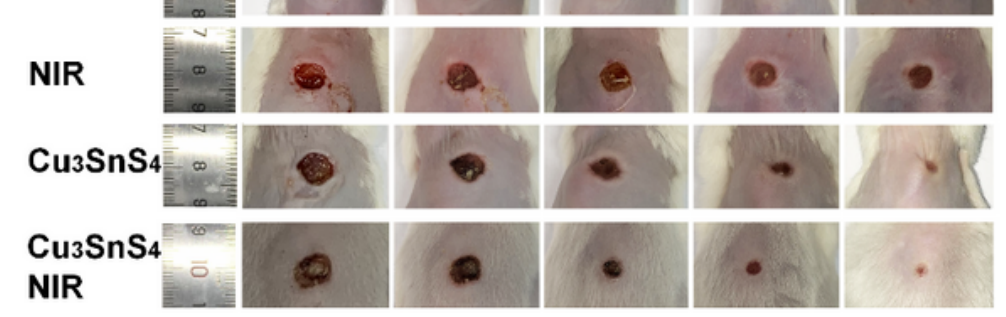

(F)

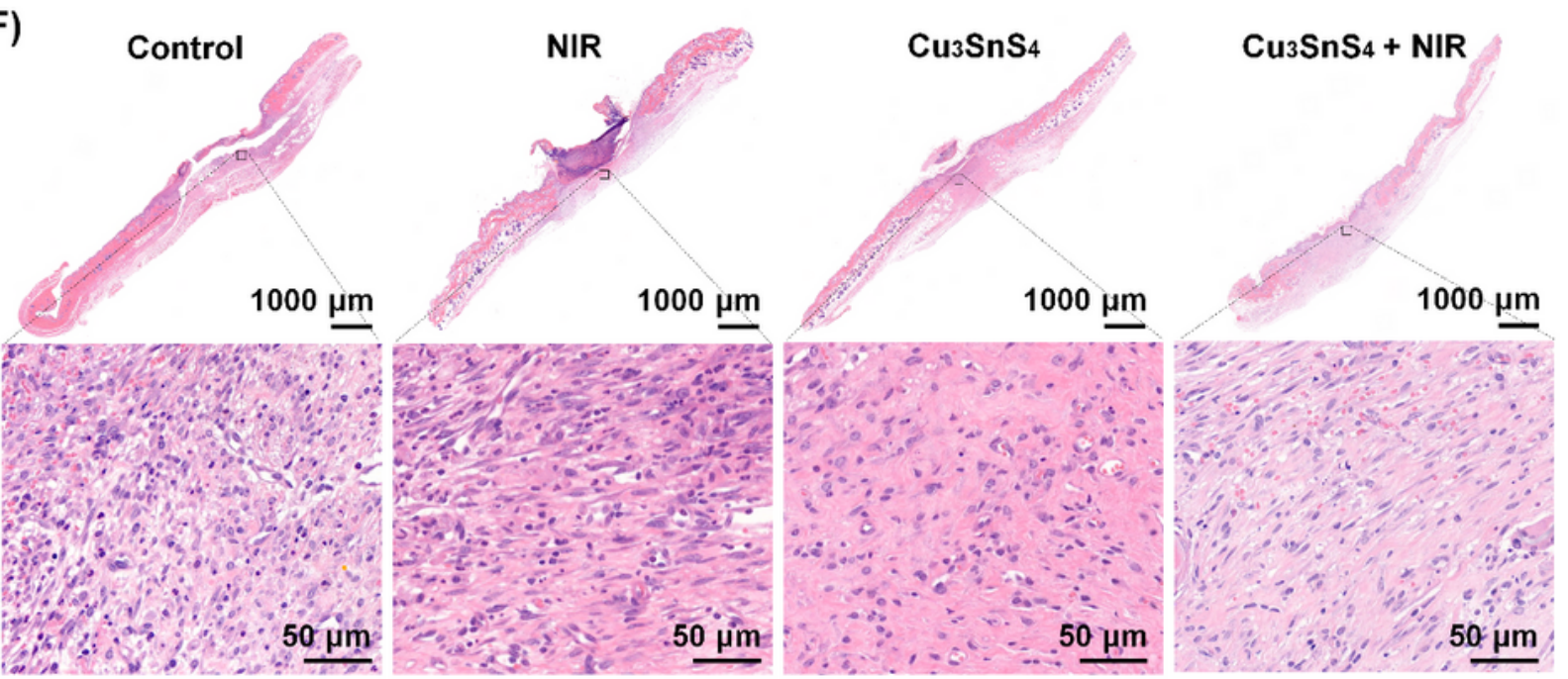

\section{Figure 6}

(A) In vivo thermal infrared images of mice after different treatments. Mice were treated with PBS or $\mathrm{Cu}_{3} \mathrm{SnS}_{4} \mathrm{NFs}$ followed by NIR laser irradiation for different times. (B) Corresponding temperature change of wounds of mice after treatment with PBS or $\mathrm{Cu}_{3} \mathrm{SnS}_{4} \mathrm{NFs}$ followed by $808 \mathrm{~nm}$ laser irradiation. (C) Scheme of the photo-activated antibacterial treatment processes. (D) Representative photographic images of ICR mice with MRSA-infected wounds after different treatments for 8 days: control (treated 
with PBS), NIR (treated with PBS followed by NIR irradiation), $\mathrm{Cu}_{3} \mathrm{SnS}_{4}$ (treated with $\mathrm{Cu}_{3} \mathrm{SnS}_{4} \mathrm{NFs}$ ), and $\mathrm{Cu}_{3} \mathrm{SnS}_{4}+\mathrm{NIR}$ (treated with $\mathrm{Cu}_{3} \mathrm{SnS}_{4} \mathrm{NFs}$ followed by NIR irradiation). (E) Corresponding changes of wound size in each group during the 8 days' treatments. Data are presented as means \pm SDs $(n=6) .{ }^{*} p<$ $0.05,{ }^{* \star} p<0.001$. (F) H\&E staining of the dermal wound tissues on day 8 after different treatments. For NIR irradiation, $808 \mathrm{~nm}$ laser $\left(1.0 \mathrm{~W} \mathrm{~cm}^{-2}, 10 \mathrm{~min}\right)$ were used.

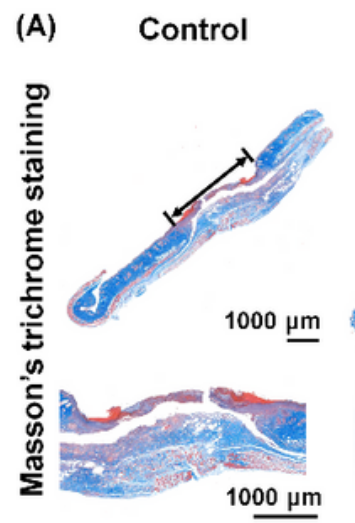

NIR
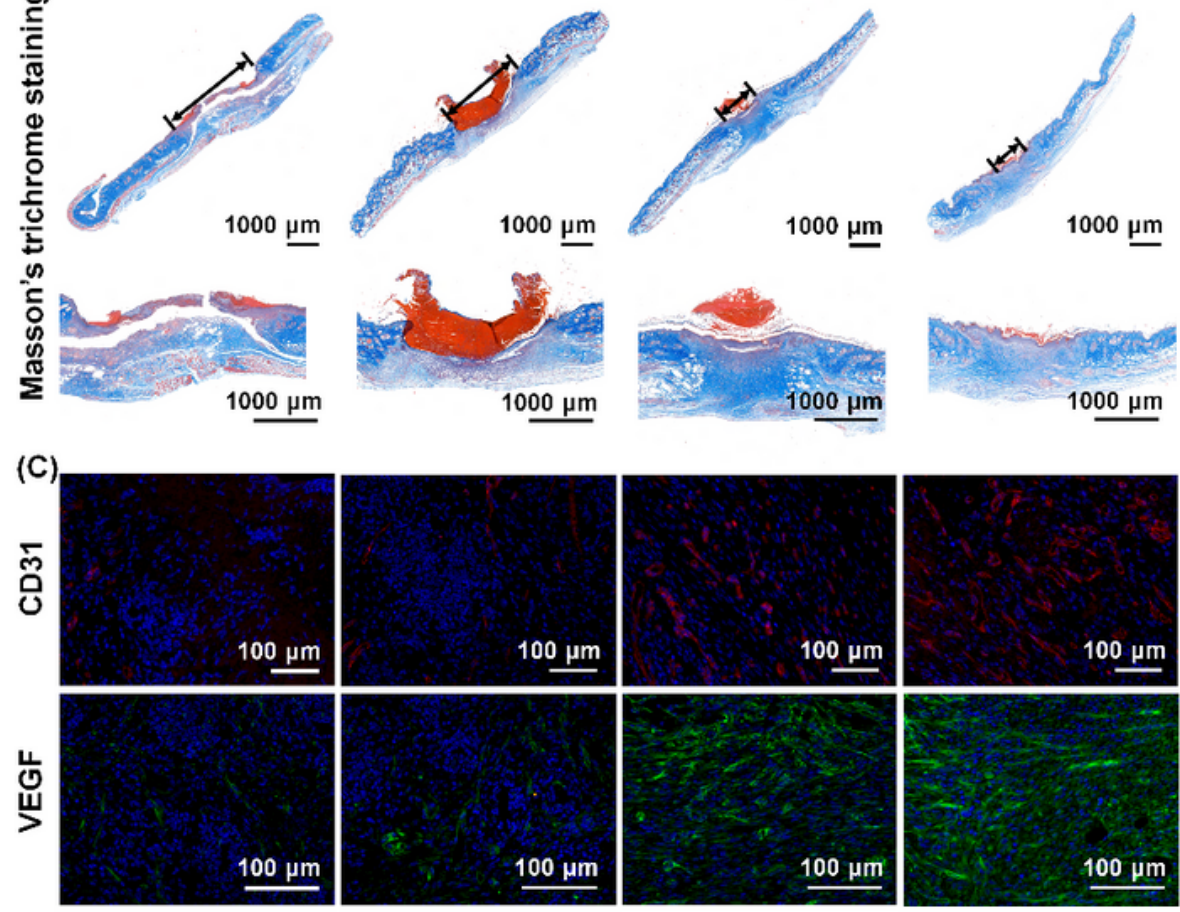

(D)

$\mathrm{Cu}_{3} \mathrm{SnS}_{4}+\mathrm{NIR} \quad$ (B)
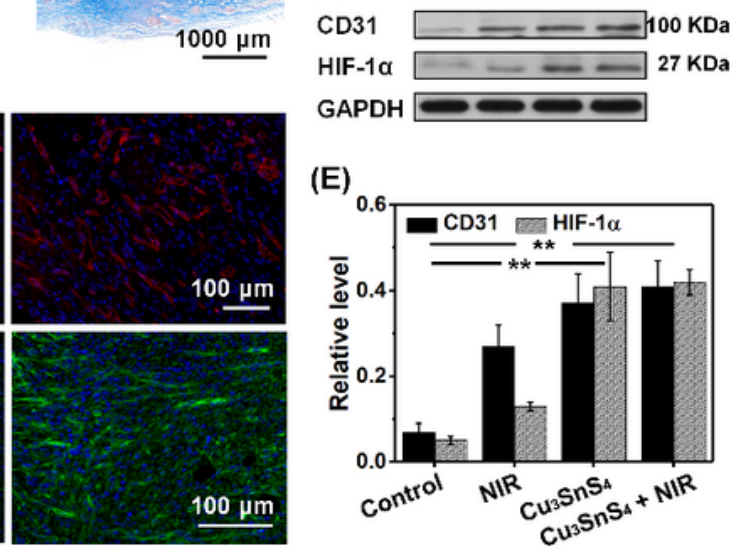
GAPDH

(E)

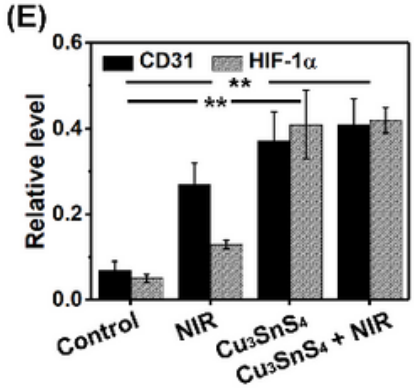

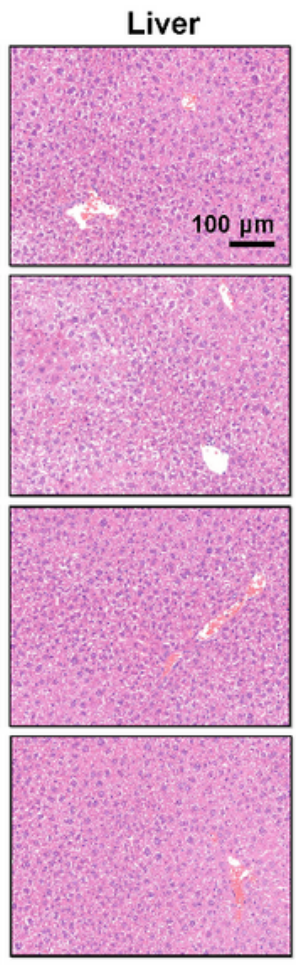
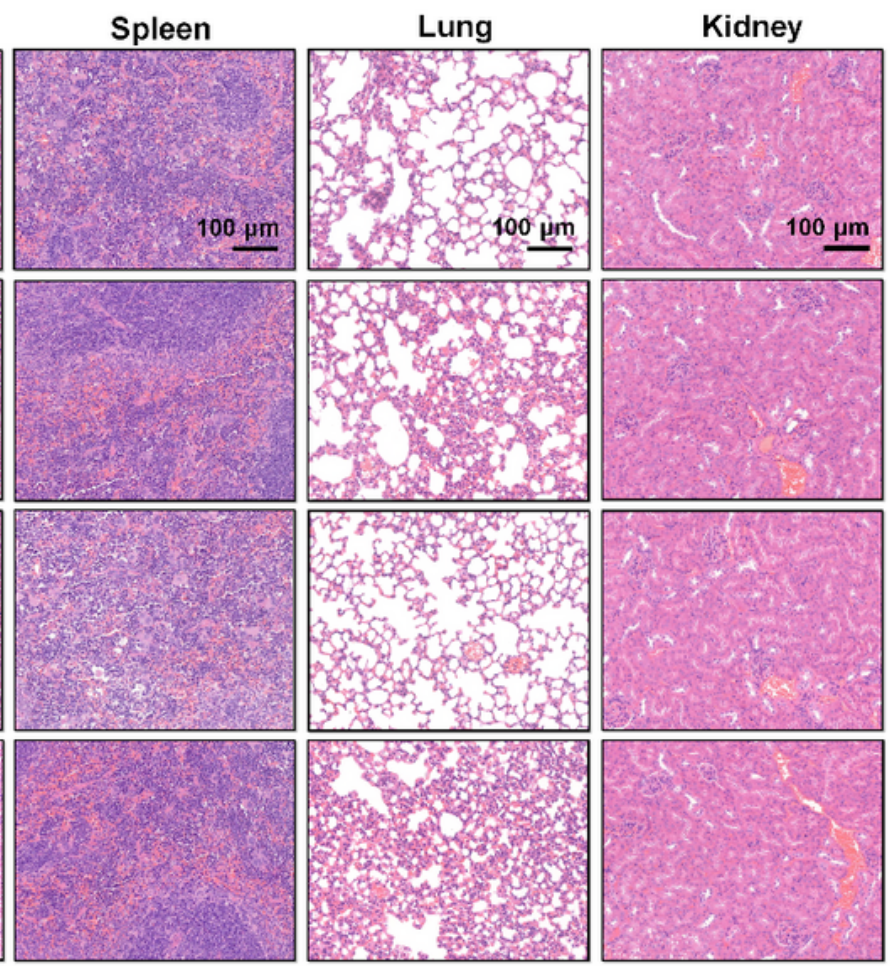


\section{Figure 7}

(A) Histopathological analysis of Masson's trichrome staining of wounds in mice on day 8 after different treatments. (B) Corresponding epithelial gap in each group after the treatment. (C) Representative histological images of CD31 and VEGF immunofluorescence staining of wound tissue in each group at the end of the 8 days' treatments. (D) Western blot analyses of CD31 and HIF-1a expressions in wound of mice in each group at the end of 8 days' treatments. (E) Corresponding quantitative level of CD31 and HIF-1a expressions in each group. (F) Representative H\&E staining images of major organs after different treatments.

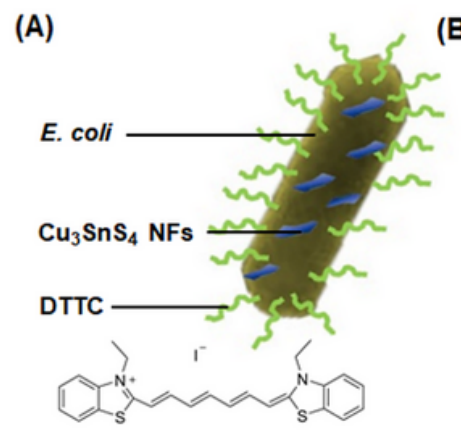

(B)

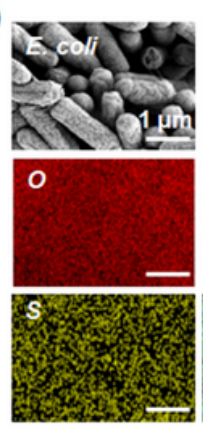

(D)

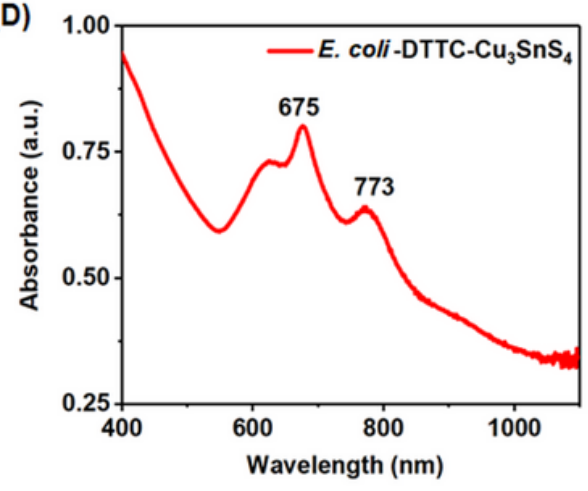

(E)

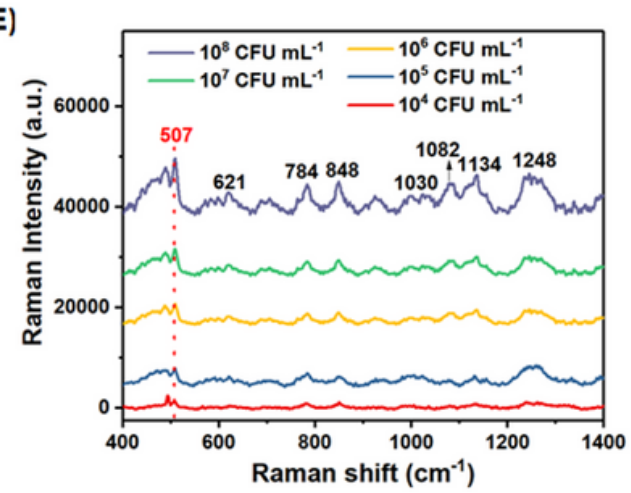

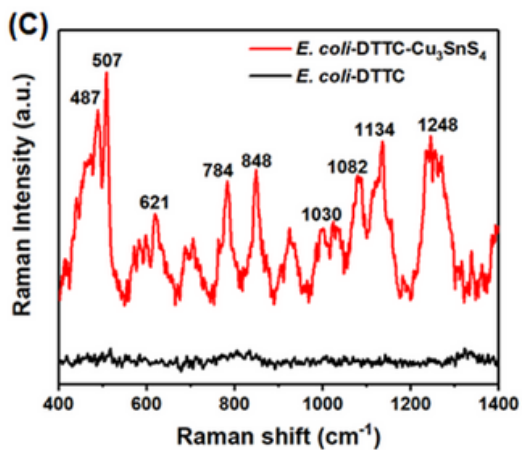

(F)

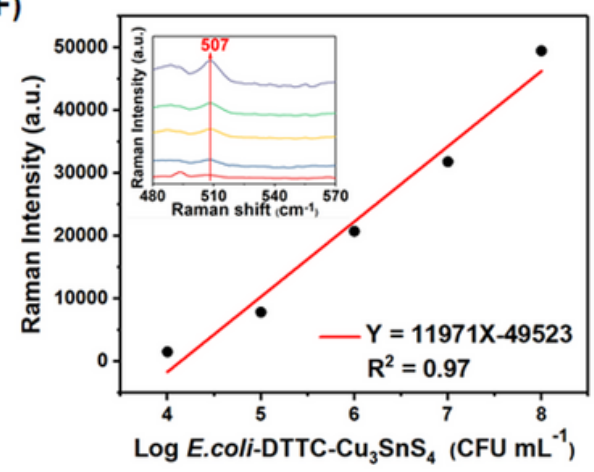

Figure 8

(A) Illustration of the E. coli-DTTC-Cu $3 \mathrm{SnS}_{4}$. (B) The SEM and EDS element mapping of the E. coli-DTTC$\mathrm{Cu}_{3} \mathrm{SnS}_{4}$. (C) The Raman spectra of E. coli-DTTC and E. coli-DTTC-Cu $\mathrm{SnS}_{4}$. (D) The UV/Vis/NIR absorption spectrum of the E. coli-DTTC- $\mathrm{Cu}_{3} \mathrm{SnS}_{4}$. (E) In vitro SERS spectra of E. coli-DTTC-Cu $\mathrm{SnS}_{4}$ under the excitation of a $785 \mathrm{~nm}$ laser. $(\mathrm{F})$ Raman peak intensity versus Log E. coli-DTTC-Cu $\mathrm{SnS}_{4}$ concentration at $507 \mathrm{~cm}^{-1}$.

\section{Supplementary Files}

This is a list of supplementary files associated with this preprint. Click to download.

- Graphicalabstract.png

- SupportingInformation.docx 